\title{
Millennial-scale variability of marine productivity and terrigenous matter supply in the western Bering Sea over the past $180 \mathrm{kyr}$
}

\author{
J.-R. Riethdorf ${ }^{1,5}$, D. Nürnberg ${ }^{1}$, L. Max ${ }^{2}$, R. Tiedemann ${ }^{2}$, S. A. Gorbarenko ${ }^{3}$, and M. I. Malakhov ${ }^{4}$ \\ ${ }^{1}$ Helmholtz Centre for Ocean Research Kiel (GEOMAR), Wischhofstr. 1-3, 24148 Kiel, Germany \\ ${ }^{2}$ Alfred Wegener Institute for Polar and Marine Research, Am Handelshafen 12, 27570 Bremerhaven, Germany \\ ${ }^{3}$ Pacific Oceanological Institute, Far Eastern Branch, Russian Academy of Sciences, Baltiskaya St. 43, \\ 690041 Vladivostok, Russia \\ ${ }^{4}$ North Eastern Interdisciplinary Science Research Institute (NEISRI), Far Eastern Branch, Russian Academy of Sciences, \\ Portovaya St. 16, 685000 Magadan, Russia \\ ${ }^{5}$ Department of Ocean Floor Geoscience, Atmosphere and Ocean Research Institute, University of Tokyo, \\ 5-1-5 Kashiwanoha, Kashiwa, Chiba 277-8564, Japan
}

Correspondence to: D. Nürnberg (dnuernberg@geomar.de)

Received: 29 November 2012 - Published in Clim. Past Discuss.: 12 December 2012

Revised: 29 April 2013 - Accepted: 13 May 2013 - Published: 26 June 2013

\begin{abstract}
We used piston cores recovered in the western Bering Sea to reconstruct millennial-scale changes in marine productivity and terrigenous matter supply over the past $\sim 180$ kyr. Based on a geochemical multi-proxy approach, our results indicate closely interacting processes controlling marine productivity and terrigenous matter supply comparable to the situation in the Okhotsk Sea. Overall, terrigenous inputs were high, whereas export production was low. Minor increases in marine productivity occurred during intervals of Marine Isotope Stage 5 and interstadials, but pronounced maxima were recorded during interglacials and Termination I. The terrigenous material is suggested to be derived from continental sources on the eastern Bering Sea shelf and to be subsequently transported via sea ice, which is likely to drive changes in surface productivity, terrigenous inputs, and upper-ocean stratification. From our results we propose glacial, deglacial, and interglacial scenarios for environmental change in the Bering Sea. These changes seem to be primarily controlled by insolation and sea-level forcing which affect the strength of atmospheric pressure systems and sea-ice growth. The opening history of the Bering Strait is considered to have had an additional impact. Highresolution core logging data (color $\mathrm{b}^{*}$, XRF scans) strongly correspond to the Dansgaard-Oeschger climate variability registered in the NGRIP ice core and support an atmospheric coupling mechanism of Northern Hemisphere climates.
\end{abstract}

\section{Introduction}

The subarctic North Pacific (N Pacific) is a high-nitrate, low-chlorophyll (HNLC) region (e.g. Kienast et al., 2004; Tyrrell et al., 2005), characterized by salinity driven stratification (permanent halocline), which is suggested to control glacial/interglacial variations in atmospheric carbon dioxide $\left(\mathrm{CO}_{2}\right)$ concentrations (Haug et al., 1999, 2005; Sigman and Boyle, 2000; Sigman et al., 2004, 2010; Jaccard et al., 2005). The halocline prevents the formation of deep water (Warren, 1983; Emile-Geay et al., 2003) and modulates the supply of nutrient-rich deep water into the euphotic zone, thereby influencing the extent of marine productivity and nitrate utilization. Since the halocline also acts as a barrier for atmospheric-oceanic gas exchange, the modern $\mathrm{N}$ Pacific, with its high carbon export efficiency (Honda et al., 2002), is considered a net sink of atmospheric $\mathrm{CO}_{2}$ (Takahashi et al., 2002a).

Several studies have reported low export production in the N Pacific during glacial times (Narita et al., 2002; Kienast et al., 2004; Jaccard et al., 2005, 2009, 2010; Brunelle et al., 2007; Shigemitsu et al., 2007; Galbraith et al., 2008; Gebhardt et al., 2008). However, it remains unclear whether this was caused by stronger stratification or by enhanced seaice cover. Both processes would result in a less efficient export of organic carbon to the deep ocean and its subsequent degradation to $\mathrm{CO}_{2}$ ("biological pump"), and hamper 
the release of deep-sequestered $\mathrm{CO}_{2}$ to the atmosphere. Interglacial maxima in export production at ODP Site 882 were related to reduced stratification rather than to sea-ice influence (Jaccard et al., 2005). Since the modern Bering Sea is marked by high marine productivity and seasonal seaice formation (e.g. Springer et al., 1996; Niebauer et al., 1999), it might have had a different influence on past oceanatmosphere $\mathrm{CO}_{2}$ exchange. Paleoceanographic reconstructions in the Bering Sea also revealed reduced export production during the last glacial period, which increased during Termination I and remained high in the Holocene (Gorbarenko, 1996; Cook et al., 2005; Gorbarenko et al., 2005; Okada et al., 2005; Okazaki et al., 2005; Brunelle et al., 2007, 2010; Itaki et al., 2009; Khim et al., 2010; Kim et al., 2011). This variability was explained by a complex interplay of changes in sea surface temperatures (SST), sea-ice coverage, inflow of Pacific surface waters, and upper-ocean stratification (e.g. Katsuki and Takahashi, 2005; Brunelle et al., 2007, 2010; Kim et al., 2011).

Knowledge of past sea-ice variability in the Bering Sea comes from diatom and radiolarian assemblages, and $\mathrm{IP}_{25}$ biomarker studies (Cook et al., 2005; Katsuki and Takahashi, 2005; Tanaka and Takahashi, 2005; Max et al., 2012). Although sea ice is considered an important transport agent for terrigenous material, geochemical or sedimentological studies assessing past terrigenous matter supply in the $\mathrm{N}$ Pacific are rare. Existing studies focused on the Okhotsk Sea (Sato et al., 2002; Nürnberg and Tiedemann, 2004; Nürnberg et al., 2011), the NW Pacific (Shigemitsu et al., 2007; VanLaningham et al., 2009), and the Southern Ocean (Latimer and Filippelli, 2001). For the Okhotsk Sea, Nürnberg and Tiedemann (2004) suggested that nearly synchronous glacial/interglacial changes in biological and terrigenous fluxes were modulated by sea-ice processes driven by variations in the strength of the Siberian High. For the Bering Sea some provenance studies involving sedimentological and geochemical characteristics of surface sediments are available, but were mainly conducted on the eastern Bering Sea shelf (Gardner et al., 1980; Lisitzin, 2002; Asahara et al., 2012; Nagashima et al., 2012). These studies and results from the Meiji Drift in the NW Pacific indicate that a large fraction of the supplied terrigenous material was delivered from Yukon-Bering Sea sources (VanLaningham et al., 2009). However, downcore records reflecting the compositional variability of terrigenous matter in the Bering Sea are missing.

Recent progress has been made in detecting millennialscale climate variability in Bering Sea sediments (Cook et al., 2005; Gorbarenko et al., 2005, 2010; Okazaki et al., 2005; Brunelle et al., 2010; Khim et al., 2010; Kim et al., 2011; Max et al., 2012; Rella et al., 2012). Most of these studies are restricted to the last $\sim 70 \mathrm{kyr}$ or focus on deglacial changes in the northern, southern, and southeastern Bering Sea. Together with studies from the NE Pacific (e.g. Hendy and Kennett, 2000) they imply that short episodes of increased ma- rine productivity are connected with interstadials recorded in Greenland ice cores. However, the existing reconstructions within the $\mathrm{N}$ Pacific realm are constrained by the shallow lysocline, which limits the use of carbonate-based proxies and causes stratigraphic uncertainties. In the Bering Sea according reconstructions are thus restricted to shallow shelf areas or topographic highs. Here, we present millennial-scale reconstructions of export production and terrigenous matter supply for the hitherto only poorly studied western Bering Sea. Results were derived from a suite of geochemical proxies and high-resolution core logging data covering the last $\sim 180 \mathrm{kyr}$.

\section{Regional setting}

The Bering Sea links the Pacific Ocean with the Arctic Ocean via the only shallow $(\sim 50 \mathrm{~m})$ Bering Strait. In its eastern and northern part it is characterized by a wide and shallow (0$200 \mathrm{~m}$ ) continental shelf area. Pacific surface waters, transported by the westward-flowing Alaskan Stream, enter the Bering Sea through several passes within the Aleutian Island Arc (e.g. Takahashi, 2005). Inside the Bering Sea, a largescale cyclonic surface circulation pattern develops with the Bering Slope Current (BSC) and the East Kamchatka Current acting as eastern and western boundary currents, respectively (Fig. 1). Outflow occurs through the Bering Strait into the Arctic Ocean and through the Aleutian passes, mainly Kamchatka Strait, into the N Pacific (Stabeno et al., 1999). Deep waters flow northward and eastward from Kamchatka Strait with return outflow above $3000 \mathrm{~m}$ water depth (Reed et al., 1993; Stabeno et al., 1999). The oceanographic and climatic conditions are characterized by a strong seasonal variability of SST and sea-ice coverage that result from the interaction of the Siberian High and the Aleutian Low. The Arctic Oscillation, Pacific Decadal Oscillation, and the Pacific-North American pattern are reported to be related with decadal variations of both atmospheric pressure cells (Niebauer, 1988, 1998; Mantua et al., 1997; Overland et al., 1999, 2002). During winter, a strong Siberian High results in advection of cold Arctic air masses and mainly northerly wind directions (Stabeno et al., 1999). This causes a significant cooling of the sea surface, sea-ice formation, as well as enhanced vertical mixing in the mixed layer, thereby returning nutrients from the subsurface. In contrast, during summer, the reduced strength of the Aleutian Low and enhanced insolation result in a stratified mixed layer and increased marine productivity.

Primary productivity is dominated by diatoms mainly blooming during spring, whereas increased biological $\mathrm{CaCO}_{3}$ fluxes (coccolithophores, planktonic foraminifera) occur during spring and late summer/early fall (e.g. Takahashi et al., 2002b). Highest annual production rates are associated with shelf areas and vary regionally between $>200$ and $>800 \mathrm{gC} \mathrm{m}^{-2}$ (Arzhanova et al., 1995; Springer et al., 1996; Stabeno et al., 1999). Available nutrients are reported 


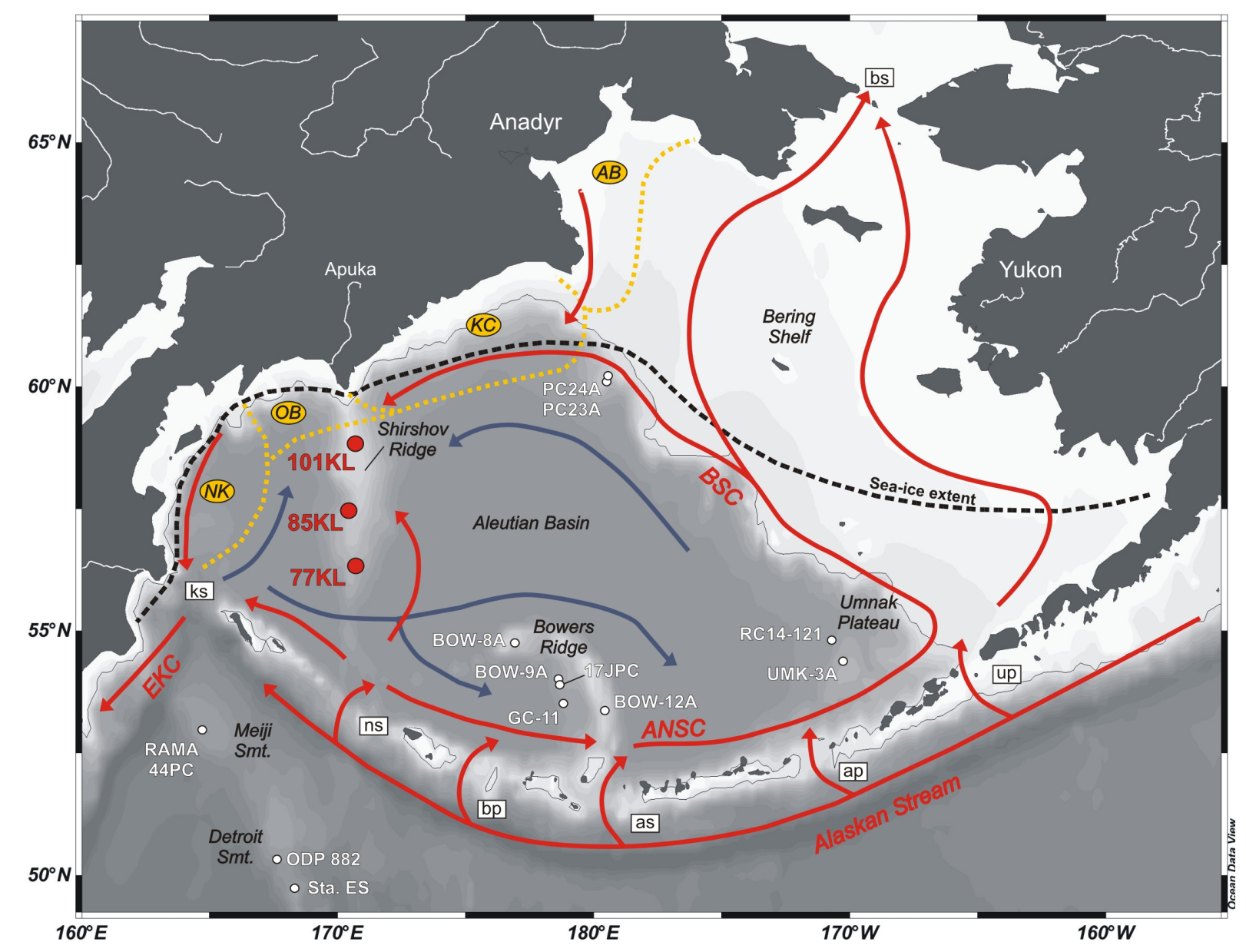

Fig. 1. Bathymetric map of the study area with $250 \mathrm{~m}$ isobathe. Locations of sediment cores SO201-2-77KL, -85KL, and -101KL are marked by red dots. White dots indicate reference records referred to in this study. Meiji Seamount: RAMA44PC (Keigwin et al., 1992). Detroit Seamount: ODP Site 882 (Jaccard et al., 2005), KH99-3 Sta. ES (Narita et al., 2002). Bowers Ridge: GC-11 (Gorbarenko, 1996; Gorbarenko et al., 2005, 2010), KH99-3-BOW-8A, -9A, and -12A (Katsuki and Takahashi, 2005; Okada et al., 2005; Okazaki et al., 2005; Tanaka and Takahashi, 2005), HLY02-02-17JPC (Brunelle et al., 2007, 2010). Umnak Plateau: KH99-3-UMK-3A (Okada et al., 2005; Okazaki et al., 2005; Tanaka and Takahashi, 2005), RC14-121 (Cook et al., 2005). Northern slope: MR06-04-PC23A and -PC24A (Itaki et al., 2009; Khim et al., 2010; Kim et al., 2011; Rella et al., 2012). Dashed black line indicates average maximum sea-ice extent (after Niebauer et al., 1999; Zhang et al., 2010). Dotted yellow line shows mineralogical provinces of coarse silts (after Lisitzin, 2002). The surface and deep circulation patterns (after Stabeno et al., 1999) are indicated by red and blue arrows, respectively. Mineralogical provinces: NK is Northern Kamchatka, OB is Olyutorskii Bay, KC is Koryak Coast, AB is Anadyr Bay. Surface currents: ANSC is Aleutian North Slope Current, BSC is Bering Slope Current, EKC is East Kamchatka Current. Straits: ks is Kamchatka Strait, ns is Near Strait, bp is Buldir Pass, as is Amchitka Strait, ap is Amukta Pass, up is Unimak Pass, bs is Bering Strait. This map was generated with "Ocean Data View” (Schlitzer, 2011).

to be often fully consumed during seasonal blooms (Niebauer et al., 1995).

Sea ice begins to form during October/November on the northern Bering Sea continental shelf (Anadyr Bay, Bering Strait), reaches its maximum distribution in March/April, and subsequently declines until July (Tomczak and Godfrey, 1994; Niebauer et al., 1999; Lisitzin, 2002). Sea-ice formation takes place in shallow shelf areas, bays, and coastal areas. As in the Arctic, coastal polynyas play an important role for the build-up of sea ice, and consequently for water mass ventilation due to brine rejection (Niebauer et al., 1999;
Stabeno et al., 1999). Processes entraining sediment into newly formed ice involve tidal sea-level oscillations, wind mixing, resuspension of sediments from the seafloor (suspension freezing), beach-ice formation, nearshore anchor ice formation, and seabed freezing (e.g. Nürnberg et al., 1994, 2011, and references therein; Stein, 2008, and references therein). Especially during fall and winter, storms affect reworking and resuspension processes by sea-ice crushing, mixing of the water column, and detachment of the sedimentladen ice from the coast. The sediment freight is released by 
sea-ice melting, especially during spring/summer, and then contributes to (hemi-) pelagic sedimentation.

\section{Material and methods}

This study is based on piston cores SO201-2-77KL, 85KL, and -101KL from Shirshov Ridge, western Bering Sea (Fig. 1, Table 1). The cores were recovered along a $\sim 280 \mathrm{~km}$-long north-south transect from intermediate to deep water levels $(630-2135 \mathrm{~m})$ during R/V Sonne cruise SO201-KALMAR Leg 2 in 2009 (Dullo et al., 2009). The sedimentary succession is characterized by monotonous sequences of mainly clay- and silt-sized siliciclastic material, which are repeatedly interrupted by layers of diatomaceous ooze. Except for the younger part of the Holocene, which mainly consists of diatom-rich sediment, our sediment cores contained low but sufficient concentrations of $\mathrm{CaCO}_{3}$ to also allow for high-resolution foraminifera-based reconstructions. However, for cores $85 \mathrm{KL}$ and $101 \mathrm{KL}$ sediments younger than 7.5 and $12.5 \mathrm{kaBP}$, respectively, were not recovered.

\subsection{Stratigraphic approach}

\subsubsection{Core logging}

Color reflectance measurements were carried out using a Minolta CM 508d hand-held spectrophotometer at $1 \mathrm{~cm}$-spaced intervals (Dullo et al., 2009). Reflectance data were automatically converted by Spectramagic software into CIE L*, a* and $b^{*}$ color space (CIELAB). The Avaatech X-ray fluorescence (XRF) core scanner at Alfred Wegener Institute for Polar and Marine Research, Bremerhaven, was used to determine relative changes in the sedimentary elemental composition. Core scanning was performed on the split core surface covered with SPEX CertiPrep 3525 Ultralene foil ( $4 \mu \mathrm{m}$ thick). Each core segment was triple-scanned for analysis of elements $\mathrm{Al}$ through to $\mathrm{Ba}$ at $1 \mathrm{~mA}$, but at different tube voltages and count times $(10 \mathrm{kV}, 10 \mathrm{~s} ; 30 \mathrm{kV}, 15 \mathrm{~s} ; 50 \mathrm{kV}, 30 \mathrm{~s})$, using a sampling resolution of $1 \mathrm{~cm}$. Results are considered semiquantitative (Richter et al., 2006; Tjallingii et al., 2007) and are given as count rates (in cps) or as log-ratios (natural logarithm) of element count rates.

\subsubsection{Stable oxygen isotopes}

For stable oxygen isotope $\left(\delta^{18} \mathrm{O}\right)$ stratigraphy we used endobenthic foraminifer species Uvigerina peregrina and Uvigerina auberiana, since Uvigerina $\delta^{18} \mathrm{O}$ values are reported to be in equilibrium with seawater (Shackleton and Hall, 1984). $\delta^{18} \mathrm{O}$ was measured every $5 \mathrm{~cm}$ on $2-3$ tests of $U$. peregrina collected from the $315-355 \mu \mathrm{m}$ size fraction. For core $77 \mathrm{KL}$ we used tests of $U$. auberiana when $U$. peregrina was not present. The measurements were performed at GEOMAR, Kiel, using a MAT253 mass spectrometer (Thermo
Scientific, Germany) coupled with a Kiel IV Carbonate device (Thermo Scientific, Germany). Results were referenced to the NBS19 standard and calibrated to the VPDB scale. Long-term precision ( $n>1000$ samples) for $\delta^{18} \mathrm{O}$ of the used carbonate standard (Solnhofen limestone) was $\pm 0.06 \%$. In core $77 \mathrm{KL}$ benthic foraminifera were only preserved until $865 \mathrm{~cm}$ core depth.

\subsubsection{Paleomagnetics}

Sedimentary natural remanent magnetization (NRM) was determined in core $85 \mathrm{KL}$ based on saturation magnetization in magnetic-hysteresis parameters, and by differential thermomagnetic analyses using a Faraday magnetic balance and a coercive spectrometer (Burov et al., 1986; Yasonov et al., 1998). The NRM module and direction were measured with a AGICO JR-5A spinner magnetometer after the stepwise demagnetization of a reference sample. Magnetic cleaning was performed using an alternating magnetic field with an amplitude of $10 \mathrm{mT}$ to recognize the characteristic component of NRM (ChRM). Anhysteretic remanent magnetization (ARM) was generated in the preliminarily demagnetized samples using a AGICO AMU-1A anhysteretic magnetizer under a constant field of $0.05 \mathrm{mT}$ and a maximum alternating field of $100 \mathrm{mT}$. Relative paleointensity of the magnetic field (RPI) was then calculated by normalization of ChRM to ARM. Scalar petromagnetic properties (SPP) were additionally determined (Enkin et al., 2007; Malakhov et al., 2009). All measurements were conducted at NEISRI, Magadan.

Takahashi et al. (2011) reported on the transformation of oxide magnetic minerals into paramagnetic $\mathrm{FeS}_{2}$ in Bering Sea sediments. They associated the formation of $\mathrm{FeS}_{2}$ with sulfate reduction processes under anaerobic methane oxidation. We performed quality control of the magnetic hysteresis parameters (Day-plot, orthogonal projections of AF demagnetization of NRM, et al.) and the thermomagnetic analyses of the magnetic fraction, which also indicate an influence by sediment diagenesis in core $85 \mathrm{KL}$. Specifically, the thermomagnetic analyses suggest the occurrence of paramagnetic $\mathrm{FeS}_{2}$ in the major ferrimagnetic phase from 880 to $1760 \mathrm{~cm}$ core depth. We assume that the dissolution of very finely dispersed, almost single-domain magnetic particles and the preservation of coarse pseudo-single-domain and multi-domain particles just led to decreasing RPI values within that depth interval. However, this most probably had no effect on the relative variability of the reconstructed geomagnetic field.

\subsubsection{Age models}

The chronostratigraphic approach included high-resolution core logging data (color $b^{*}$, XRF scanning), benthic $\delta^{18} \mathrm{O}$ stratigraphy, magnetostratigraphy, and accelerator mass spectrometry (AMS) radiocarbon dating of planktonic foraminifera for absolute age control. A detailed presentation 
Table 1. Site information.

\begin{tabular}{lccrr}
\hline Core & Latitude & Longitude & Depth (m b.s.1.) & Recovery $(\mathrm{m})$ \\
\hline SO201-2-77KL & $56^{\circ} 19.83^{\prime} \mathrm{N}$ & $170^{\circ} 41.98^{\prime} \mathrm{E}$ & 2135 & 11.78 \\
SO201-2-85KL & $57^{\circ} 30.30^{\prime} \mathrm{N}$ & $170^{\circ} 24.77^{\prime} \mathrm{E}$ & 968 & 18.13 \\
SO201-2-101KL & $58^{\circ} 52.52^{\prime} \mathrm{N}$ & $170^{\circ} 41.45^{\prime} \mathrm{E}$ & 630 & 18.32 \\
\hline
\end{tabular}

of the stratigraphic framework for the last $20 \mathrm{kyr}$, including the AMS- ${ }^{14} \mathrm{C}$ dating results, is provided in Max et al. (2012). The pre-deglacial ( $>20 \mathrm{kaBP}$ ) stratigraphic framework of our cores is primarily based on the graphic correlation between color $\mathrm{b}^{*}$ recorded in core $85 \mathrm{KL}$ and the Dansgaard-Oeschger (D-O; e.g. Dansgaard et al., 1993) climate variability registered in the NGRIP $\delta^{18} \mathrm{O}$ record (NGRIP members, 2004; GICC05 timescale, Rasmussen et al., 2006) (Fig. 2a). For ages $>122 \mathrm{ka} \mathrm{BP}$ and for identification of the Marine Isotope Stage (MIS) 5.5 climate optimum $(\sim 125 \mathrm{ka} \mathrm{BP})$ color $\mathrm{b}^{*}$ and XRF Ca/Ti log-ratios were correlated to the Sanbao stalagmite $\delta^{18} \mathrm{O}$ record (Wang et al., 2008). The Laschamp ( $42 \mathrm{ka} \mathrm{BP})$, Norwegian-Greenland Sea $(\sim 65 \mathrm{kaBP})$, and Blake $(\sim 117 \mathrm{ka} \mathrm{BP})$ paleomagnetic excursions were identified in the RPI record and correlated with the PISO-1500 geomagnetic paleointensity stack (Channell et al., 2009). Further ages were derived from comparison of benthic $\delta^{18} \mathrm{O}$ values and SPP (not shown) with the global reference stack LR04 (Lisiecki and Raymo, 2005), which was also used to identify boundaries of MIS 1 to 6 . The stratigraphy of core $85 \mathrm{KL}$ was transferred via intercore correlations (color $\mathrm{b}^{*}, \mathrm{XRF} \mathrm{Ca} / \mathrm{Ti} \log$-ratios) to cores $77 \mathrm{KL}$ and $101 \mathrm{KL}$ (Fig. 2b), for which similar stratigraphic approaches were carried out. All age-depth points are provided in Appendix A.

Figure 3 shows the age models for our cores by direct comparison with the used reference records and a respective age versus depth diagram. Age models were tested via spectral analysis of the color $\mathrm{b}^{*}$ and benthic $\delta^{18} \mathrm{O}$ records in the time domain to detect orbital frequencies. Spectral analysis was performed using the AnalySeries 2.0 software (Paillard et al., 1996). Despite the shortness of our records with respect to orbital-scale changes, we found dominant cyclicities of $\sim 23$ and $\sim 39 \mathrm{kyr}$, which within appropriate bandwidths match frequencies of orbital precession $\left(0.047 \pm 0.005 \mathrm{kyr}^{-1}\right)$ and obliquity cycles $\left(0.025 \pm 0.0015 \mathrm{kyr}^{-1}\right)$ (Fig. 3$)$.

\subsection{Sedimentation and accumulation rates}

Linear sedimentation rates (LSR, in $\mathrm{cm} \mathrm{kyr}^{-1}$ ) were calculated between age control points. Bulk accumulation rates $\left(\mathrm{AR}_{\mathrm{Bulk}}\right.$, in $\mathrm{g} \mathrm{cm}^{-2} \mathrm{kyr}^{-1}$ ) were calculated as the product of LSR and the dry bulk density (DBD, in $\mathrm{g} \mathrm{cm}^{-3}$, determined each $5 \mathrm{~cm}$ ). Records of LSR and AR Bulk are shown in Fig. 4. Cores from Shirshov Ridge have average LSR $\left(\mathrm{AR}_{\mathrm{Bulk}}\right)$ of $11-16 \mathrm{~cm} \mathrm{kyr}^{-1}\left(7-15 \mathrm{~g} \mathrm{~cm}^{-2} \mathrm{kyr}^{-1}\right)$, and hence allow for centennial- to millennial-scale reconstructions. Variability

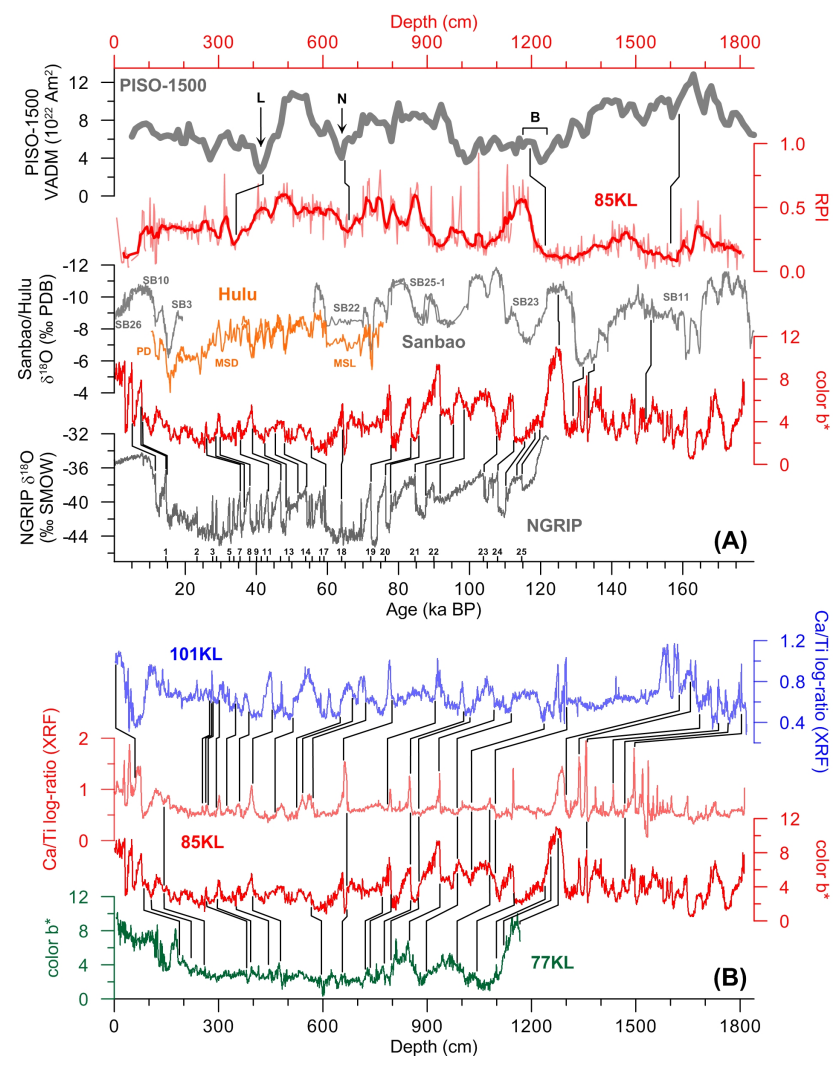

Fig. 2. (A) Correlation of sediment core SO201-2-85KL with the PISO-1500 (thick grey line) paleomagnetic reference record (Channell et al., 2009) based on relative paleointensity (RPI, smoothed by a 5-point-running average), as well as with the Sanbao (grey lines) and Hulu (orange lines) stalagmite $\delta^{18} \mathrm{O}$ records (Wang et al., 2001, 2008) and the NGRIP $\delta^{18} \mathrm{O}$ record (NGRIP members, 2004; GICC05 timescale, Rasmussen et al., 2006) based on color b*. Black lines mark correlation lines. The Laschamp (L), NorwegianGreenland Sea $(\mathrm{N})$, and Blake (B) paleomagnetic events are indicated. Bottom numbers mark D-O events. (B) Intercore correlation of sediment cores SO201-2-77KL (green) and -101KL (blue) with core $-85 \mathrm{KL}$ (red) is based on color $\mathrm{b}^{*}$ and $\mathrm{XRF} \mathrm{Ca} / \mathrm{Ti} \log$-ratio records.

and average values of $\mathrm{LSR}$ and $\mathrm{AR}_{\mathrm{Bulk}}$ increase toward the northernmost site. In general, LSR and $\mathrm{AR}_{\mathrm{Bulk}}$ are higher during cold intervals (MIS 6, 5.4, 5.2, and 4) than during warm intervals (MIS 5.5, 5.3, 5.1, 3, and 1), but highest during Termination I (20-10 ka BP) (Fig. 4). Holocene sediments are either not fully recovered or subject to low LSR 

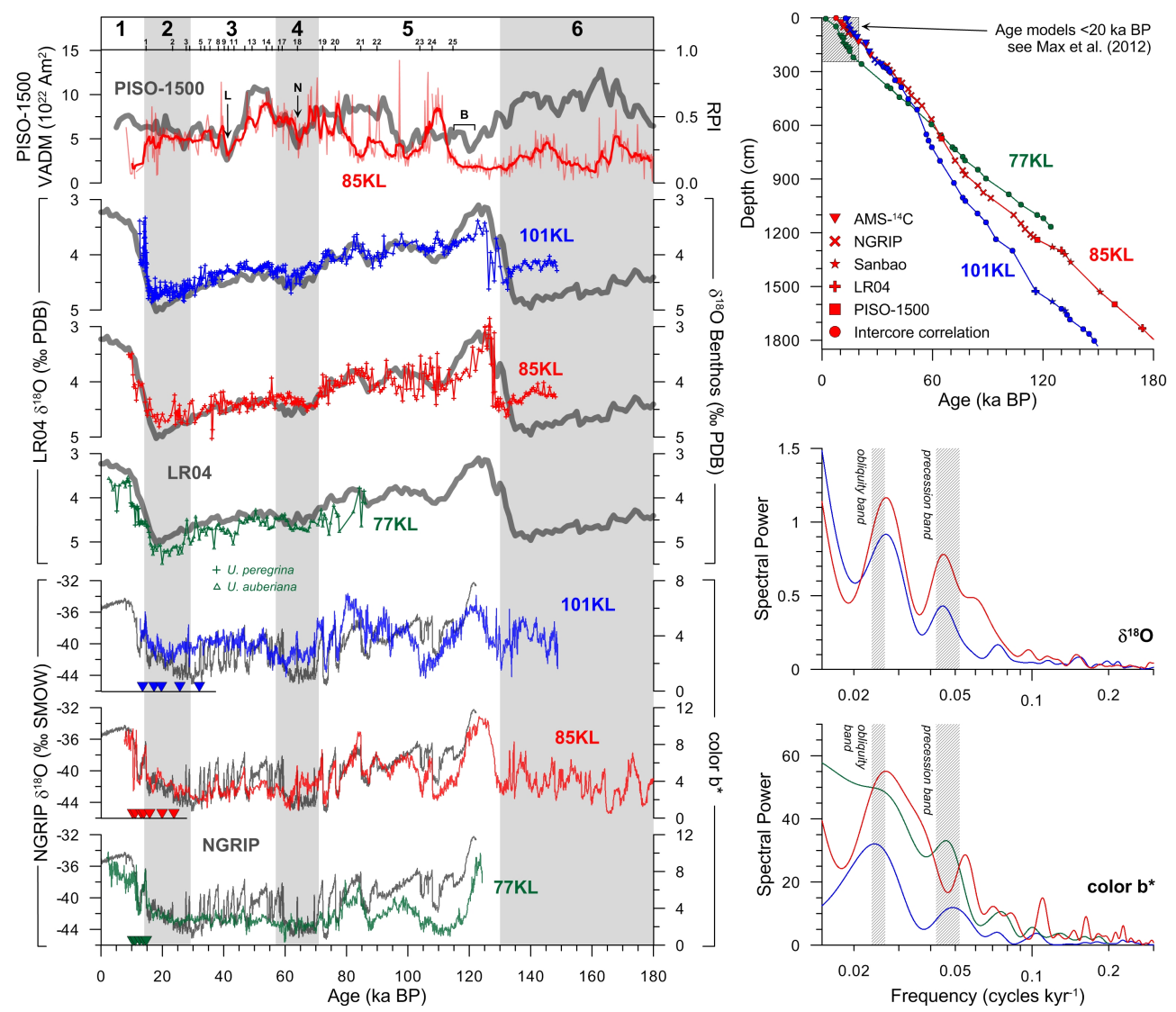

Fig. 3. Left: comparison of proxy records from sediment cores SO201-2-77KL (green lines), -85KL (red lines), and -101KL (blue lines) with published reference records (grey lines). Age models are primarily based on the graphic correlation between color $\mathrm{b}^{*}$ records and the NGRIP $\delta^{18} \mathrm{O}$ record (NGRIP members, 2004; GICC05 timescale, Rasmussen et al., 2006). Benthic $\delta^{18} \mathrm{O}$ values from $U$. peregrina (plus symbols) and $U$. auberiana (open triangles) are in agreement with the global reference stack LR04 (Lisiecki and Raymo, 2005). Relative paleointensity (RPI, smoothed by a 5-point-running average) recorded in core $85 \mathrm{KL}$ compares with the paleomagnetic reference record PISO1500 (Channell et al., 2009). L, N, and B mark the Laschamp, Norwegian-Greenland Sea, and Blake paleomagnetic events. Absolute age control is provided by AMS- ${ }^{14} \mathrm{C}$-dating (coloured triangles; see Max et al., 2012). Top numbers indicate Marine Isotope Stages (boundaries after Lisiecki and Raymo, 2005) and D-O events. Upper right: age versus depth diagram showing the age-depth points and their underlying stratigraphic approach (see also Appendix A). Lower right: spectral analysis of benthic $\delta^{18} \mathrm{O}$ and color $\mathrm{b}^{*}$ records performed in the time domain revealed dominant cyclicities that lie within the frequency bands of Earth's obliquity and precession cycles.

$\left(\mathrm{AR}_{\mathrm{Bulk}}\right)$. The piston should have prevented sediment loss during coring and at least giant piston cores are reported to rather cause oversampling (stretching) of the sediments (Széréméta et al., 2004). We therefore consider the partly missing Holocene sections to be the result of a change in sedimentation favoring the deposition of highly porous diatomaceous ooze and its subsequent erosion. If proxy concentrations in marine sediment cores are low or vary only little, the variability of accumulation rates mainly reflects the LSR variability (Middelburg et al., 1997). This situation applied to our sediment cores. Accordingly, we mainly report proxy concentrations rather than quantified flux rates and treat the respective records as qualitative.

\subsection{Assessment of marine productivity}

Past changes in marine productivity (paleo-export production) were approximated from total organic carbon (TOC), $\mathrm{CaCO}_{3}$, biogenic opal, biogenic barium $\left(\mathrm{Ba}_{\text {bio }}\right)$, and XRF logging data. This multi-proxy approach was necessary due to specific restrictions of the respective proxies. TOC preservation in sediments is highly debated (e.g. Hartnett et al., 1998; Ganeshram et al., 1999; Thunell et al., 2000; Hedges et al., 2001) as it is, e.g. influenced by oxidation processes and bottom water ventilation (De La Rocha, 2007). Also, its source can be of marine and terrestrial origin. In the $\mathrm{N}$ Pacific the preservation of $\mathrm{CaCO}_{3}$ is limited by the shallow lysocline. Accordingly, $\mathrm{CaCO}_{3}$ concentrations rather reflect changes in the bottom water calcite saturation state (e.g. Jaccard et al., 2005; Gebhardt et al., 2008), although changes in 


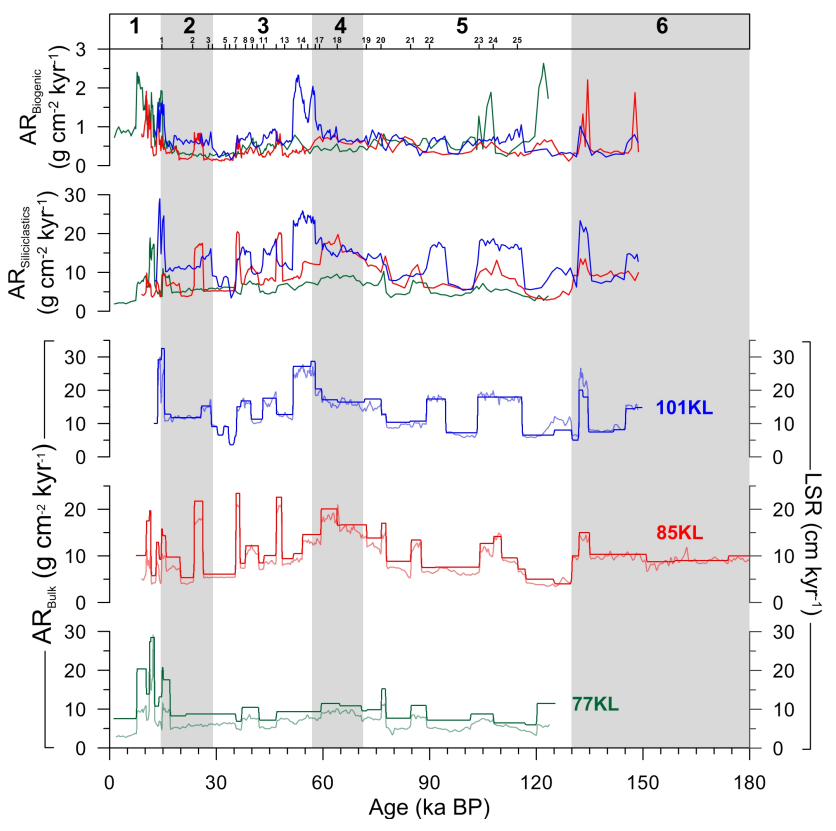

Fig. 4. 'Accumulation rates of biogenic components (sum of $\mathrm{CaCO}_{3}$, TOC, and opal; $\mathrm{AR}_{\text {Biogenic }}$ ) and siliciclastics $\left(\mathrm{AR}_{\text {Siliciclastics }}\right)$, as well as bulk accumulation rates $\left(\mathrm{AR}_{\mathrm{Bulk}}\right.$; transparent lines) and linear sedimentation rates (LSR) of sediment cores SO201-2-77KL (green), -85KL (red), and -101KL (blue). LSR and $\mathrm{AR}_{\mathrm{Bulk}}$ are plotted on the same scale per core.

biological $\mathrm{CaCO}_{3}$ production can not be fully excluded to explain changes in $\mathrm{CaCO}_{3}$. Opal dissolves during settling to the seafloor, but its preservation is independent from bottom water oxygenation. Since opal-rich sediments are linked to biogenic silica production (e.g. Honjo, 1990; Nelson et al., 1995; Ragueneau et al., 2000; Pondaven et al., 2000) biogenic opal is most often used in $\mathrm{N}$ Pacific reconstructions of marine productivity. Barium, present as sedimentary barite is used in several studies to reconstruct paleoproductivity (e.g. Dymond et al., 1992; Francois et al., 1995; Dymond and Collier, 1996; Gingele et al., 1999). Barite particles occur in areas of high new production (Dehairs et al., 1991) and laboratory experiments showed that the decay of phytoplankton in undersaturated seawater results in barite formation (Ganeshram et al., 2003).

\subsubsection{CN-analyses and biogenic opal}

Total carbon (TC), TOC, and total nitrogen (TN) were determined on freeze-dried bulk sediment samples of $20 \mathrm{mg}$ using a Carlo Erba NA-1500 CNS analyzer. TOC was measured on previously decalcified samples and $\mathrm{CaCO}_{3}$ concentrations were calculated by multiplication of the difference between TC and TOC with a factor of 8.333. Reproducibility of the TOC and TN measurements was $\pm 0.03 \mathrm{wt} \%$ and $\pm 0.01 \mathrm{wt} \%$, respectively.
The molar ratio of TOC to TN, corrected for inorganic nitrogen compounds (referred to as $[\mathrm{C} / \mathrm{N}] \mathrm{a}$ hereafter), was used to distinguish between marine and terrestrial sources of TOC. The Redfield ratio (Redfield et al., 1963) translates the C/N ratio of marine organic matter to $\sim 7$. Typical terrigenous values lie between 20-200 (Hedges et al., 1986). We applied a correction for total inorganic nitrogen (TIN), usually claybound inorganic ammonium (Müller, 1977), based on a linear relationship between TOC and TN (after Goñi et al., 1998). Results showed TIN concentrations of $0.01-0.02 \mathrm{wt} \%$ that were assumed constant downcore.

Biogenic opal was measured following Müller and Schneider (1993) using molybdate-blue spectrophotometry. Silica was extracted from $20 \mathrm{mg}$ of freeze-dried bulk sediment samples. Results were evaluated applying the procedure of DeMaster (1981). Replicate measurements showed a reproducibility of $1-2 \mathrm{wt} \%$.

\subsubsection{Biogenic barium (Babio)}

Concentrations of major ( $\mathrm{Al}, \mathrm{Ti}, \mathrm{Fe}, \mathrm{K})$ and trace $(\mathrm{Ba})$ elements were determined on discrete samples of $0.6 \mathrm{~g}$ of freeze-dried bulk sediment using a Philips PW1480 XRF spectrometer without determination of loss on ignition following standard procedures. Analytical precision, determined for the BHVO standard, was $<2 \%$ RSD for the major elements and $\pm 30 \mathrm{ppm}$ for $\mathrm{Ba}(\mathrm{N}=15)$. Results for barium $\left(\mathrm{Ba}_{\text {total }}\right)$ are the sum of biogenic $\left(\mathrm{Ba}_{\mathrm{bio}}\right)$ and nonbiogenic $\mathrm{Ba}-$ portions. $\mathrm{Ba}_{\mathrm{bio}}$ was therefore calculated via concentrations of $\mathrm{Al}$ by estimating the aluminosilicate contribution of $\mathrm{Ba}$ considering the global average $\mathrm{Ba} / \mathrm{Al}$ ratio for pelitic rocks of $6.5 \mathrm{mg} \mathrm{g}^{-1}$ (Wedepohl, 1971):

$\mathrm{Ba}_{\text {bio }}=\mathrm{Ba}_{\text {total }}-\mathrm{Al} * 0.0065$

$B a_{\text {bio }}$ was subsequently used to assess new production $\left(P_{\text {New }}\right)$ by applying the relationship of Nürnberg (1995) (see also Fig. 7). Annual primary production (PP) was calculated after Eppley and Peterson (1979) using the $P_{\mathrm{New}}$ estimates.

\subsubsection{XRF logging data $(\mathrm{Br}, \mathrm{Ca} / \mathrm{Ti}, \mathrm{Si} / \mathrm{Al})$}

Several logging data and bulk geochemical analyses showed a similar temporal evolution. In this respect, XRF count rates of $\mathrm{Br}$ correlated with TOC concentrations $\left(0.35<R^{2}<0.74\right)$, which supports a relationship between TOC and biophilic halogen bromine (Ziegler et al., 2008). $\mathrm{XRF} \mathrm{Ca} / \mathrm{Ti} \log$-ratios correlated with $\mathrm{CaCO}_{3}$ concentrations $\left(0.07<R^{2}<0.65\right)$, which is explained by assuming a detrital origin of Ti. Normalization of XRF-derived $\mathrm{Ca}$ to $\mathrm{Ti}$ and/or $\mathrm{Al}$ abundances has been applied before (Jaccard et al., 2005) and is thought to reflect biogenic $\mathrm{CaCO}_{3}$ contents within the sediment. The XRF signals for $\mathrm{Al}$ were better than for Ti and were subsequently used for normalization. However, we favored $\mathrm{Ca} / \mathrm{Ti}$ over $\mathrm{Ca} / \mathrm{Al} \log$-ratios due to better correlation to $\mathrm{CaCO}_{3}$. Although opal concentrations 
were close to reproducibility for most samples, they correlated with color $\mathrm{b}^{*}\left(0.20<R^{2}<0.60\right)$ and XRF Si/Al $\log$-ratios $\left(0.04<R^{2}<0.73\right)$. This is in accordance with other studies considering a connection between $\mathrm{Si} / \mathrm{Al}$ ratios and biogenic opal (McDonald et al., 1999) and between color b* and organic matter/opal (Debret et al., 2006). All linear relationships found are strong for cores $77 \mathrm{KL}$ and $85 \mathrm{KL}\left(0.57<R^{2}<0.74\right)$, but weak for core $101 \mathrm{KL}$ $\left(0.04<R^{2}<0.35\right)$. Since the linear correlation coefficients strongly varied between both, the respective sites and the respective proxies, the logging data were not used to apply calibration functions, but are shown together with the quantitative results.

\subsection{Assessment of terrigenous matter supply}

\subsubsection{Coarse material, siliciclastics, and terrigenous matter}

Changes in terrigenous fluxes were approximated from a set of sedimentological and geochemical proxies together with XRF logging data. The proportions of coarse $(>63 \mu \mathrm{m})$ and fine $(<63 \mu \mathrm{m})$ material (in wt \%) were determined every $5 \mathrm{~cm}$ by weighing of the dried sediment before and after wet-sieving through a $63 \mu \mathrm{m}$ mesh. Magnetic susceptibility (not shown) was logged using a GEOTEK Multi-Sensor Core Logger in combination with a Bartington MS2C sensor loop each $1 \mathrm{~cm}$ on the unopened core segments directly after recovery (Dullo et al., 2009). Records of $>63 \mu \mathrm{m}$ showed only weak relationships with magnetic susceptibility records $\left(R^{2}<0.13\right)$, which were characterized by low values $(<15$ SI units). Hence, magnetizable minerals are most probably mainly bound to the fine fractions.

Relative amounts of siliciclastics (\% Siliciclastics) were calculated by considering the bulk sediment to be composed of siliciclastics, $\mathrm{CaCO}_{3}$, TOC, and biogenic opal. TN concentrations were generally $<0.3 \mathrm{wt} \%$ and not included in the calculation:

$\%$ Siliciclastics $=100 \%-\left(\mathrm{CaCO}_{3} \%+\mathrm{TOC} \%+\mathrm{Opal} \%\right)$

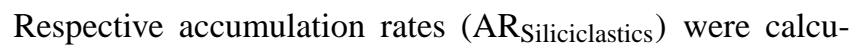
lated by dividing \%Siliciclastic by 100 and subsequent multiplication with $\mathrm{AR}_{\mathrm{Bulk}}$. The accumulation rate of the biogenic components $\left(\mathrm{AR}_{\mathrm{Biogenic}}\right)$ was calculated by subtracting $\mathrm{AR}_{\text {Siliciclastics }}$ from $\mathrm{AR}_{\text {Bulk. }}$.

In a second approach, relative amounts of terrigenous matter (\% Terrigen) were calculated by normalizing bulk sedimentary $\mathrm{Al}$ and $\mathrm{Ti}$ concentrations to their concentration in average continental crust $\left(\mathrm{Al}=3117 \mu \mathrm{mol} \mathrm{g} \mathrm{g}^{-1}\right.$, $\mathrm{Ti}=112.8 \mu \mathrm{mol} \mathrm{g}^{-1}$; Taylor and McLennan, 1995). Both normalizations resulted in a similar temporal evolution of the records, but Al-normalized results, which were on average 4$6 \%$ higher than Ti-normalized results, better compared to the records of \% Siliciclastics.

\subsubsection{Lithogenous elements}

The geochemistry of lithogenous elements can be used to approximate continental input (e.g. Duce and Tindale, 1991; Bareille et al., 1994), dust supply (e.g. Boyle, 1983; Calvert and Fortugne, 2001), terrestrial runoff (e.g. Schmitz, 1987; Jansen et al., 1998), and mineralogical variations (e.g. Schneider et al., 1997; Yarincik et al., 2000). As described above, concentrations of $\mathrm{Al}, \mathrm{Ti}, \mathrm{Fe}$, and $\mathrm{K}$ were determined via discrete XRF bulk analyses. The elements and their respective ratios were used to identify sources of terrigenous matter and to reconstruct variations in terrigenous fluxes. In cores $85 \mathrm{KL}$ and $101 \mathrm{KL}$ XRF logging data of $\mathrm{K} / \mathrm{Ti}$ log-ratios correlated well with molar K/Ti ratios $\left(R^{2}>0.64\right)$ and are shown for comparison.

\section{Results and discussion}

\subsection{Marine productivity}

\subsubsection{Proxy data}

Our records for export production show a similar temporal evolution in all cores. Proxy concentrations increase toward the southernmost site, whereas the ranges of $\mathrm{AR}_{\text {Biogenic }}$ are comparable and low for all sites $\left(<3 \mathrm{~g} \mathrm{~cm}^{-2} \mathrm{kyr}^{-1}\right.$; Fig. 4). Results for TOC, opal, $\mathrm{CaCO}_{3}$, as well as their approximating logging data are shown in Fig. 5. In general, concentrations and their approximating XRF data remained low during cold intervals (MIS 6, 5.4, 5.2, 4 to 2), but high during warm intervals (MIS 5.5, 5.3, 5.1, and 1), with maximum values recorded during interglacials in core $77 \mathrm{KL}$. Core 101KL exhibits lowest proxy concentrations and amplitude variations (Table 2). Overall concentrations hardly exceed $\sim 1 \mathrm{wt} \%$ for TOC, $\sim 3 \mathrm{wt} \%$ for opal, and $\sim 2 \mathrm{wt} \%$ for $\mathrm{CaCO}_{3}$. MIS 5.3 and 5.1, as well as interstadials are characterized by $\sim 1$ to 3 -times higher values at most. Notably, cores $85 \mathrm{KL}$ and $101 \mathrm{KL}$ recorded interstadial-like events during MIS 6 (at $\sim 173,164,148,137$, and $133 \mathrm{ka} \mathrm{BP}$ ), characterized by increased proxy concentrations or their approximating XRF data. Deglacial and interglacial maxima in TOC, opal, and $\mathrm{CaCO}_{3}$ reach values of $\sim 2, \sim 50$, and $\sim 30 \mathrm{wt} \%$, respectively. Maxima recorded during Termination I reflect the warm phases of the Bølling-Allerød (B/A; 14.7-12.9 ka BP, Blockley et al., 2012) and Preboreal (PB; $\sim 11.7-11.0 \mathrm{kaBP}$ ), whereas deglacial minima are considered to correspond to the Heinrich Stadial 1 (HS1; 18.0$14.7 \mathrm{ka}$ BP, Sarnthein et al., 2001) and Younger Dryas cold phases (YD; 12.9-11.7 ka BP, Blockley et al., 2012).

During Termination I, TOC appears to lead the deglacial increase of the other productivity proxies by $\sim 2 \mathrm{kyr}$ at our sites, which is in agreement with previous results from the whole Bering Sea realm (Gorbarenko, 1996; Okazaki et al., 2005; Kim et al., 2011). Although records of TOC and XRF count rates of $\mathrm{Br}$ correspond well in our cores (Fig. 5), $\mathrm{Br}$ 


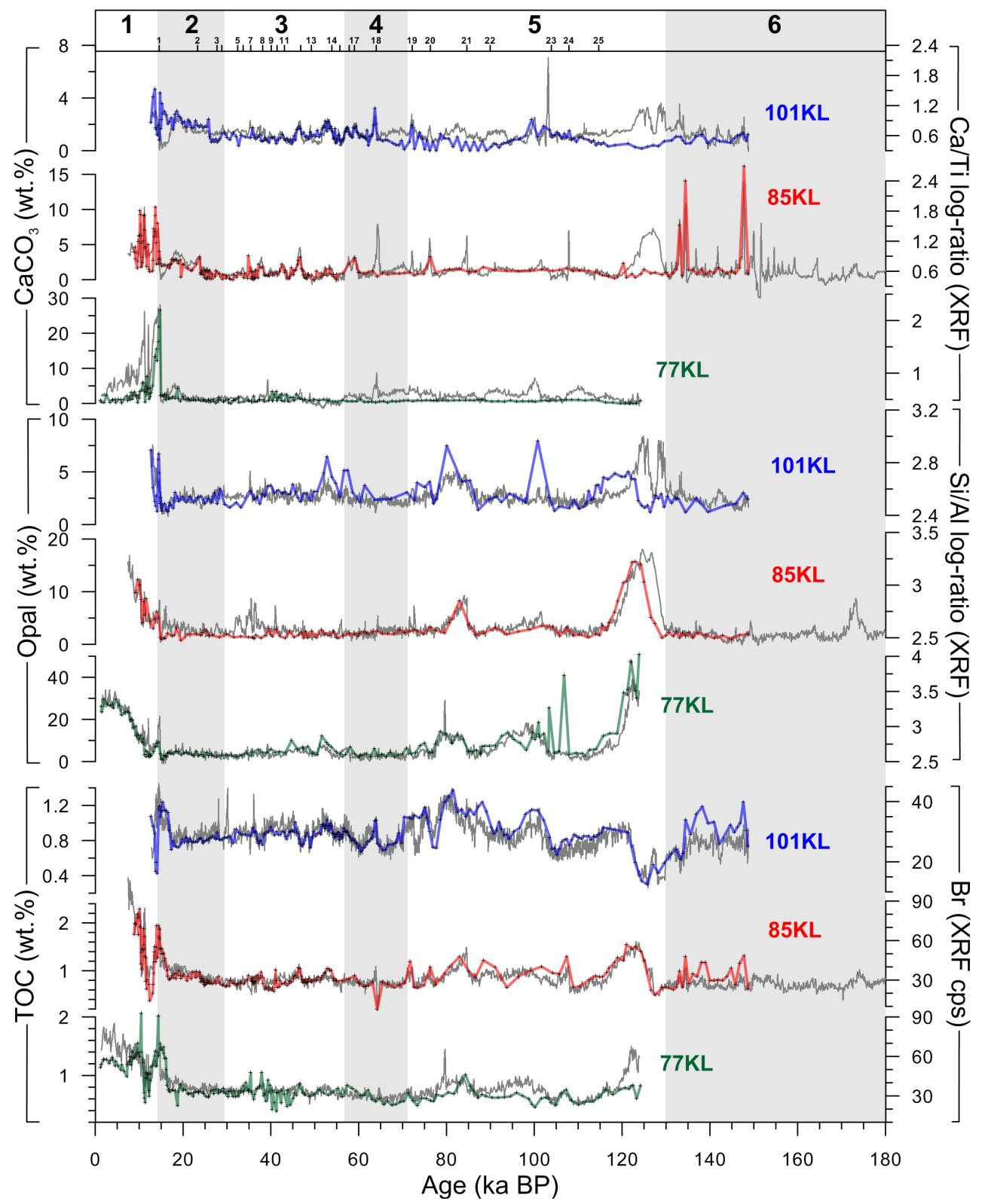

Fig. 5. Proxy records from cores SO201-2-77KL (green lines), -85KL (red lines), and -101KL (blue lines) approximating changes in marine productivity over the last $180 \mathrm{kyr}$. Concentrations of TOC, biogenic opal, and $\mathrm{CaCO}_{3}$ (coloured lines), are shown in comparison to XRF records of $\mathrm{Br}$ (in cps), as well as XRF $\mathrm{Si} / \mathrm{Al}$ and $\mathrm{Ca} / \mathrm{Ti}$ log-ratios (underlying grey lines), respectively.

does not follow this deglacial TOC increase, suggesting a changing source of TOC. In contrast to TOC and $\mathrm{CaCO}_{3}$, we observed only minor increases in opal during the $\mathrm{B} / \mathrm{A}$, but a subsequent gradual increase into the Holocene. These results from the western Bering Sea are comparable to opal records from the northern slope (Itaki et al., 2009; Khim et al., 2010; Kim et al., 2011). Despite showing a similar temporal evolution, opal records from Bowers Ridge (Okada et al., 2005; Okazaki et al., 2005; Brunelle et al., 2007, 2010), Umnak Plateau (Okada et al., 2005; Okazaki et al., 2005), and the southern Okhotsk Sea (Gorbarenko, 1996; Gorbarenko et al., 2002a, b; Narita et al., 2002; Brunelle et al., 2010) have 1.5 to 3 -times higher values.

$\mathrm{CaCO}_{3}$ concentrations at our sites are generally low and related to the abundance of foraminifera and nannoplanktonic remains (coccoliths). High XRF Ca/Ti log-ratios during MIS 5.5 are the result of decreased XRF counts of Ti and not of increased Ca counts. Short-lived increases of up to $\sim 3 \mathrm{wt} \%$ were recorded during MIS 6 , interstadials, and Termination I (Fig. 5). Similar observations, especially for Termination I, were also reported for cores from the northern slope, Bowers Ridge, and Umnak Plateau (Cook et al., 2005; 
Table 2. Statistics of parameters approximating marine productivity.

\begin{tabular}{lrrrrrr}
\hline Parameter & \multicolumn{2}{c}{ SO201-2-77KL } & \multicolumn{2}{r}{ SO201-2-85KL } & \multicolumn{2}{r}{ SO201-2-101KL } \\
\hline & Avg. & StDev. & Avg. & StDev. & Avg. & StDev. \\
\hline TOC $(\mathrm{wt} \%)$ & 0.85 & 0.30 & 0.96 & 0.36 & 0.88 & 0.16 \\
{$[\mathrm{C} / \mathrm{N}] \mathrm{a}$} & 13.0 & 2.9 & 11.9 & 1.6 & 12.4 & 1.6 \\
Opal $(\mathrm{wt} \%)$ & 9.5 & 9.7 & 3.3 & 3.2 & 2.9 & 1.3 \\
$\mathrm{CaCO}_{3}(\mathrm{wt} \%)$ & 1.9 & 3.2 & 1.9 & 2.2 & 1.2 & 0.7 \\
$\mathrm{Ba}_{\text {bio }}^{(1)}(\mathrm{ppm})$ & 733 & 330 & 436 & 141 & 260 & 85 \\
$P_{\mathrm{New}}^{(2)}\left(\mathrm{gC} \mathrm{m}^{-2} \mathrm{yr}^{-1}\right)$ & 50.6 & 47.5 & 34.9 & 21.5 & 29.9 & 21.1 \\
$\mathrm{PP}^{(3)}\left(\mathrm{gC} \mathrm{m}^{-2} \mathrm{yr}^{-1}\right)$ & 131.9 & 54.2 & 113.1 & 34.8 & 102.9 & 37.6 \\
\hline
\end{tabular}

(1) $\mathrm{Via} \mathrm{Al}$ using the global average $\mathrm{Ba} / \mathrm{Al}$ of pelitic rocks of $6.5 \mathrm{mg} \mathrm{g}^{-1}$ (Wedepohl, 1971). (2) After Nürnberg (1995). (3) After Eppley and Peterson (1979).

Okazaki et al., 2005; Brunelle et al., 2007, 2010; Itaki et al., 2009; Khim et al., 2010; Kim et al., 2011). At ODP Site 882 in the $\mathrm{N}$ Pacific interglacial maxima in $\mathrm{CaCO}_{3}$ are accompanied by maxima in $\mathrm{Ba}_{\text {bio }}$ (Jaccard et al., 2005). Since enhanced preservation of $\mathrm{CaCO}_{3}$ is explained by a release of deep-sequestered $\mathrm{CO}_{2}$ from the deep-ocean basin (Broecker and Peng, 1987; Marchitto et al., 2005), these $\mathrm{CaCO}_{3}$ maxima were suggested to be the result of a higher bottom water calcite saturation state in response to the weakening of the $\mathrm{N}$ Pacific halocline (Jaccard et al., 2005). Deglacial maxima of $\mathrm{CaCO}_{3}$ in Bering Sea sediments were also explained by denitrification on continental shelves, which might have resulted in an increase in alkalinity and, thus, in enhanced carbonate preservation (Chen, 2002; Okazaki et al., 2005). Today, the calcite saturation horizon in the Bering Sea is reported to lie above $500 \mathrm{~m}$ water depth (Feely et al., 2002) and at our sites lies above $200 \mathrm{~m}$ water depth (Riethdorf et al., 2013). Accordingly, we consider $\mathrm{CaCO}_{3}$ maxima in our cores to mainly reflect a higher bottom water calcite saturation state, but enhanced biological $\mathrm{CaCO}_{3}$ production can not be ruled out.

\subsubsection{Organic carbon source}

Average concentrations of bulk sedimentary TN varied at $\sim 0.1 \mathrm{wt} \%$. Hence, sediments from Shirshov Ridge contain a considerable amount of TIN, which results in $[\mathrm{C} / \mathrm{N}] \mathrm{a}$ ratios that are by up to 4 units higher than (uncorrected) $\mathrm{C} / \mathrm{N}$ ratios (Fig. 6a). $[\mathrm{C} / \mathrm{N}]$ a ratios in our cores mainly vary between 10 and 15 (Fig. 6a, Table 2), indicating that TOC input contains considerable amounts of terrestrial organic material. These values compare to those found at the northern slope (Khim et al., 2010) and in the central Okhotsk Sea (Nürnberg and Tiedemann, 2004). For the eastern and southern part of the Aleutian Basin (Nakatsuka et al., 1995) and for the southern Okhotsk Sea (Ternois et al., 2001) lower C/N ratios of 6-9 were reported. All our records show a rise in $[\mathrm{C} / \mathrm{N}]$ a ratios during Termination I. At Site 77KL, the deglacial increase in $[\mathrm{C} / \mathrm{N}] \mathrm{a}$ ratios starts at $\sim 17 \mathrm{kaBP}$, with maximum values during the YD, and a subsequent decrease into the Holocene. The same deglacial evolution was observed at the northern slope (Khim et al., 2010) and in the southern Okhotsk Sea (Ternois et al., 2001; Seki et al., 2003). It was related to the discharge of terrestrial material from the flooded shelf due to sea-level rise. In contrast, cores from the eastern and southern Bering Sea show a gradual decrease of $\mathrm{C} / \mathrm{N}$ ratios since the last glacial maximum (LGM) (Nakatsuka et al., 1995).

\subsubsection{Ba bio $_{\text {and export production }}$}

Our records of Babio are shown in Fig. 7 and overall match the TOC and opal records, which argues against a preservation effect due to sulfate reduction and associated barite dissolution. Accordingly, we consider changes in $\mathrm{Ba}_{\text {bio }}$ concentrations to mainly reflect variations in $\mathrm{Ba}_{\text {bio }}$ accumulation. A potential source of error in the calculation of $\mathrm{Ba}_{\text {bio }}$ comes from estimating the aluminosilicate contribution of $\mathrm{Ba}$ via $\mathrm{Al} . \mathrm{Ba} / \mathrm{Al}$ ratios range between $5-10 \mathrm{mg} \mathrm{g}^{-1}$ in crustal rocks (Taylor, 1964; Rösler and Lange, 1972) with a crustal average of $7.5 \mathrm{mg} \mathrm{g}^{-1}$ (Dymond et al., 1992). We estimated the regional detrital $\mathrm{Ba} / \mathrm{Al}$ ratio from surface sediment samples following Klump et al. (2000), which resulted in a value of $7 \mathrm{mg} \mathrm{g}^{-1}$ (unpublished data). This value is close to the global average of pelitic rocks of $6.5 \mathrm{mg} \mathrm{g}^{-1}$ (Wedepohl, 1971), which was used for reconstructing $B a_{\text {bio }}$ in the central Okhotsk Sea (Nürnberg and Tiedemann, 2004). $\mathrm{Ba}$ bio variability is low during most of the time covered by the cores, with average concentrations increasing from Site $101 \mathrm{KL}(\sim 300 \mathrm{ppm})$, via Site $85 \mathrm{KL}(\sim 400 \mathrm{ppm})$, to Site $77 \mathrm{KL}(\sim 500 \mathrm{ppm})$ (Fig. 7, Table 2$)$. Significant increases only occurred at Site 77KL during MIS 5.5 and the Holocene with concentrations of $\sim 1000 \mathrm{ppm}$ and $\sim 1700 \mathrm{ppm}$, respectively. Also at Site 77KL, XRF Ba/Al log-ratios covary with $\mathrm{Ba}_{\text {bio }}$ concentrations (not shown; $R^{2}=0.74$ ), thereby revealing minor increases during MIS 5.3, 5.1, and short-lived maxima during interstadials. A similar range and variability as found for core $77 \mathrm{KL}$ was observed at Bowers Ridge (Brunelle et al., 2007), ODP Site 882 (Jaccard et al., 2005), 

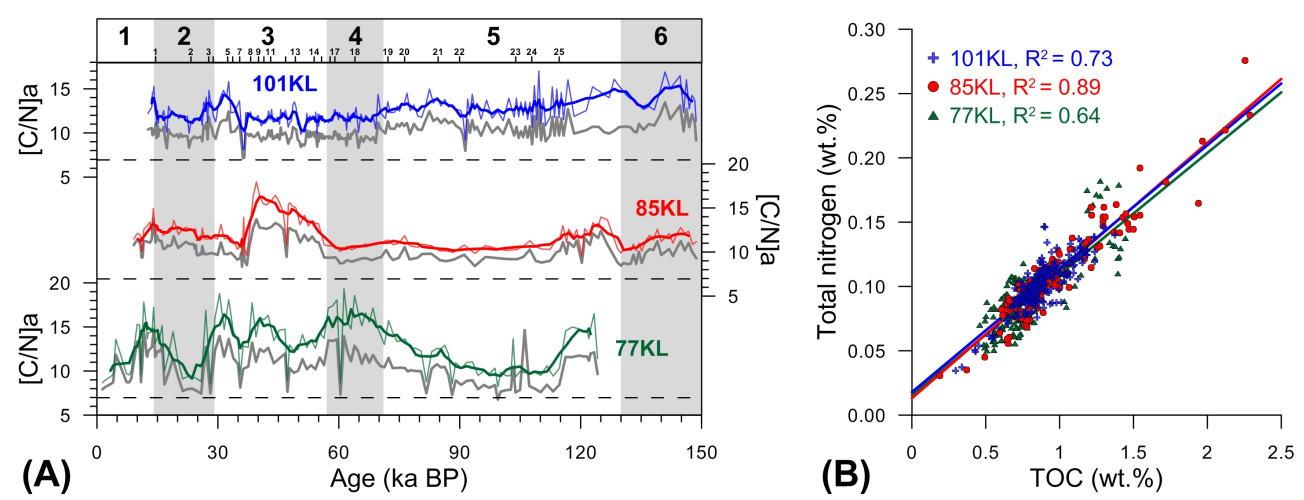

Fig. 6. (A) $[\mathrm{C} / \mathrm{N}] \mathrm{a}$ ratios (colored lines, smoothed by a 5-point-running average), corrected for inorganic nitrogen compounds, and uncorrected molar $\mathrm{C} / \mathrm{N}$ ratios (underlying grey lines) for cores SO201-2-77KL (green line), -85KL (red line), and -101KL (blue line) over the past $150 \mathrm{kyr}$. Dashed horizontal lines mark a $\mathrm{C} / \mathrm{N}$ ratio of 7 . Lower values represent typically marine-derived organic matter. (B) Linear regressions between TOC and TN conducted for each core result in intercept-values that reflect the amount of inorganic nitrogen (TIN). TN contents corrected for TIN were subsequently used to calculate $[\mathrm{C} / \mathrm{N}] \mathrm{a}$ ratios.

as well as in the sea-ice-free Antarctic Zone of the Southern Ocean (Nürnberg et al., 1997). Cores from the southern (Brunelle et al., 2010) and central Okhotsk Sea (Sato et al., 2002; Nürnberg and Tiedemann, 2004), as well as from the sea-ice-influenced Antarctic Zone of the Southern Ocean (Nürnberg et al., 1997) exhibit generally lower glacial ( 200-400 ppm) and peak interglacial ( 800-1000 ppm) contents of $\mathrm{Ba}_{\mathrm{bio}}$, being more comparable to sites $85 \mathrm{KL}$ and 101KL. Notably, Sato et al. (2002) and Brunelle et al. (2010) for the Okhtosk Sea report a deglacial lead in the rise of $\mathrm{Ba}_{\text {bio }}$ prior to that observed for opal contents, which we can not verify from our records.

We calculated $P_{\text {New }}$, i.e. primary production that results from allochthonous nutrient inputs to the euphotic zone, from $\mathrm{Ba}_{\text {bio }}$ following Nürnberg (1995) rather than from TOC, which at our sites is affected by terrestrial carbon (Fig. 7). This approach was also followed by Nürnberg and Tiedemann (2004) for a respective reconstruction in the Okhotsk Sea. Surface sediment samples from Shirshov Ridge reveal a north-south gradient in modern $P_{\mathrm{New}}$ values within $\sim 3-54 \mathrm{gC} \mathrm{m}^{-2} \mathrm{yr}^{-1}$, translating into PP values of $\sim 35-$ $145 \mathrm{gC} \mathrm{m}^{-2} \mathrm{yr}^{-1}$ (estimated from $P_{\text {New }}$, see Appendix B). Considering the uncertainties for $\mathrm{AR}_{\mathrm{Bulk}}$ and $\mathrm{Ba}_{\mathrm{bio}}$, this result is in agreement with Springer et al. (1996), who reported a modern PP range of $50-100 \mathrm{gC} \mathrm{m}^{-2} \mathrm{yr}^{-1}$ (average of $61 \mathrm{gC} \mathrm{m}^{-2} \mathrm{yr}^{-1}$ ) for the "oceanic domain" of the Bering Sea, in which our sites are located. On the eastern Bering Sea shelf edge, modern PP is reported to lie between $175-275 \mathrm{gC} \mathrm{m}^{-2} \mathrm{yr}^{-1}$ (Springer et al., 1996). Stabeno et al. (1999) reported modern PP values of $>200 \mathrm{gC} \mathrm{m}^{-2} \mathrm{yr}^{-1}$ over the southeastern shelf and $>800 \mathrm{gC} \mathrm{m}^{-2} \mathrm{yr}^{-1}$ north of St. Lawrence Island, whereas Arzhanova et al. (1995) found $>400 \mathrm{gC} \mathrm{m}^{-2} \mathrm{yr}^{-1}$ over the western shelf.

Our downcore results for $P_{\mathrm{New}}$ show that primary production was commonly low $\left(<50 \mathrm{gC} \mathrm{m}^{-2} \mathrm{yr}^{-1}\right)$ at our sites during most of the last $180 \mathrm{kyr}$ (Fig. 7, Table 2). Only core 77KL is characterized by two maxima $>150 \mathrm{gC} \mathrm{m}^{-2} \mathrm{yr}^{-1}$ during Termination I. Although these maxima correspond to higher concentrations of $\mathrm{Ba}_{\text {bio }}$, they are likely overestimated due to the use of $\mathrm{AR}_{\mathrm{Bulk}}$ in the calculation of $P_{\mathrm{New}}$. Nevertheless, our downcore results are comparable to those reported for the central Okhotsk Sea (Nürnberg and Tiedemann, 2004) and the Antarctic continental margin (Gingele et al., 1999), albeit these show lower glacial values of $<10 \mathrm{gC} \mathrm{m}^{-2} \mathrm{yr}^{-1}$. $\mathrm{PP}$ mainly remained below $150 \mathrm{gC} \mathrm{m}^{-2} \mathrm{yr}^{-1}$ at our sites (not shown). Only the deglacial $P_{\text {New }}$ maxima in core $77 \mathrm{KL}$ would translate into significantly higher PP values of $\sim 250$ $300 \mathrm{gC} \mathrm{m}^{-2} \mathrm{yr}^{-1}$ (Table 2). Consequently, PP most probably remained permanently low at our sites and never reached values as observed today on the eastern Bering Sea shelf.

\subsection{Terrigenous matter supply}

\subsubsection{Proxy data}

Sediments from Shirshov Ridge contain on average $>85 \%$ siliciclastics and only $<10 \%$ coarse material (Table 3 ), thereby tying terrigenous matter mainly to the fine fractions. Light microscope observations reveal silt to fine sand-sized, angular-shaped quartz grains as major components, supplemented by minor portions of feldspar and mica. Dropstones $(1-2 \mathrm{~cm}$ in diameter) appear as well-rounded pebbles, but they are commonly rare although occurring over the entire length of the cores. The records approximating terrigenous matter supply exhibit a similar temporal evolution at our sites (Fig. 8), but in contrast to the productivity proxies decreasing concentrations toward the southernmost site are observed. This and the observation that proxy records reflecting export production and terrigenous matter supply are negatively correlated is mainly attributed to sedimentary dilution by the biogenic components. However, changes in $\mathrm{AR}_{\mathrm{Bulk}}$ (and LSR) are obviously largely determined by changes in 

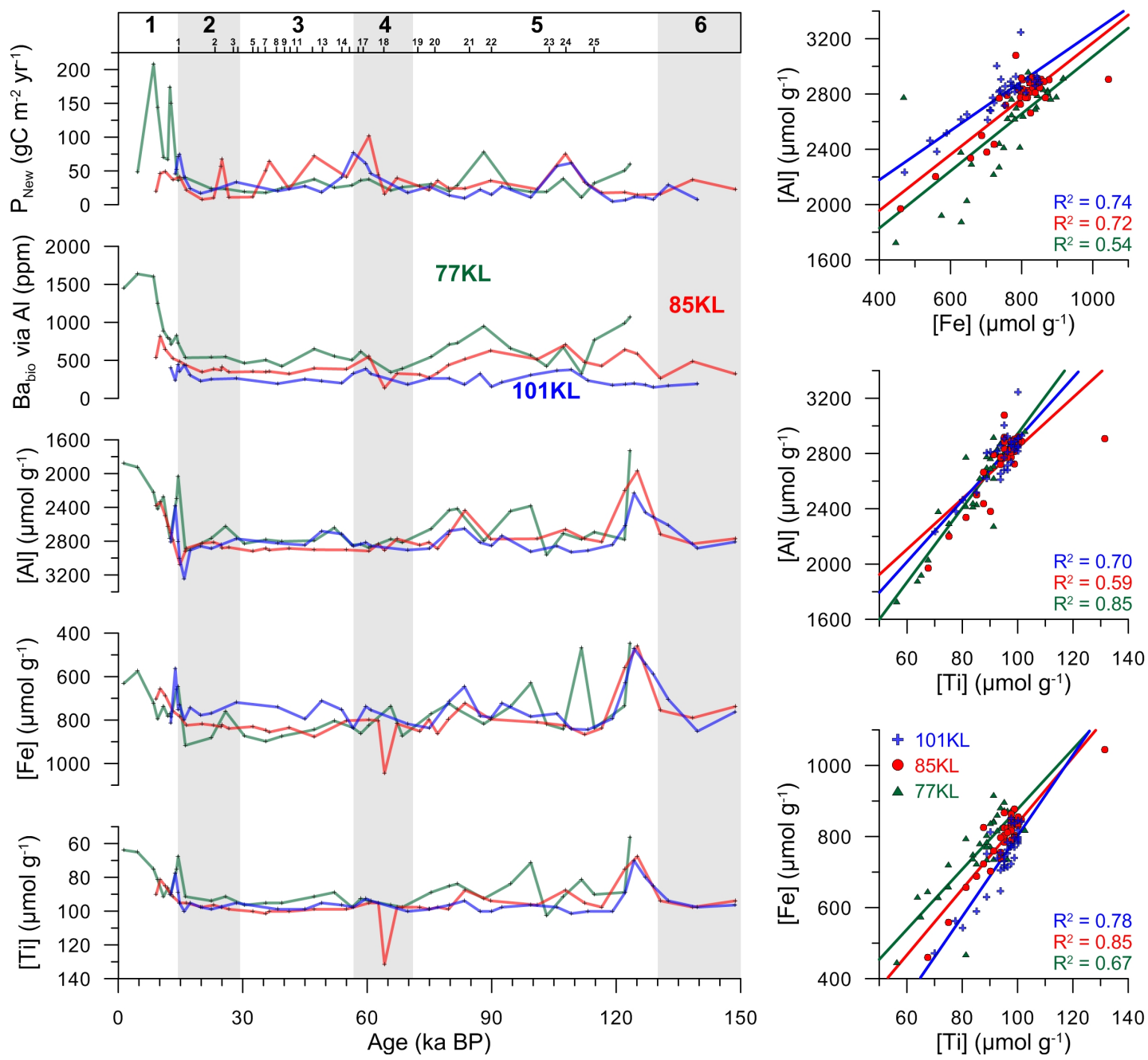

Fig. 7. Left: concentrations of lithogenous elements Ti, Fe, and $\mathrm{Al}$ (angular brackets), as well as of biogenic barium (Babio) and new production $\left(\mathrm{P}_{\mathrm{New}}\right.$ ) for the last $150 \mathrm{kyr}$. $P_{\mathrm{New}}$ was calculated from $\mathrm{Ba}_{\mathrm{bio}}$ using the equation of Nürnberg $(1995): P_{\mathrm{New}}=3.56 * \mathrm{~F} \mathrm{Ba}$ bio ${ }^{1.504} \mathrm{z}^{-0.0937}$, where $\mathrm{F} \mathrm{Ba}$ bio $=\mathrm{AR} \mathrm{Ba}$ bio $/\left[0.209 * \log _{10}\left(\mathrm{AR}_{\mathrm{Bulk}} * 1000\right)-0.213\right]$ (Dymond et al., 1992), and $z=$ water depth (in $\mathrm{m}$ ). $\mathrm{F} \mathrm{Ba}$ bio is the flux of biogenic $\mathrm{Ba}$ to the seafloor (in $\mu \mathrm{g} \mathrm{cm}^{-2} \mathrm{yr}^{-1}$ ), $\mathrm{AR} \mathrm{Ba}$ bio is the accumulation rate of biogenic $\mathrm{Ba}$ (in mg cm${ }^{-2} \mathrm{kyr}^{-1}$ ). Note that for records of [Ti], [Fe], and [Al] y-axes are inverted. Right: correlation between lithogenous elements and respective linear correlation coefficients $\left(R^{2}\right)$ indicate a shared terrigenous source of these elements.

Table 3. Statistics of parameters approximating terrigenous matter supply.

\begin{tabular}{|c|c|c|c|c|c|c|}
\hline \multirow[t]{2}{*}{ Parameter } & \multicolumn{2}{|c|}{ SO201-2-77KL } & \multicolumn{2}{|c|}{ SO201-2-85KL } & \multicolumn{2}{|c|}{ SO201-2-101KL } \\
\hline & Avg. & StDev. & Avg. & StDev. & Avg. & StDev. \\
\hline$>63 \mu \mathrm{m}(\mathrm{wt} \%)$ & 5.6 & 3.1 & 7.5 & 5.4 & 7.9 & 7.4 \\
\hline$\%$ Siliciclastics & 88.9 & 8.8 & 94.1 & 4.4 & 94.9 & 1.5 \\
\hline$\%$ Terrigen (Al-norm.) ${ }^{(1)}$ & 82.7 & 10.2 & 88.2 & 7.3 & 89.3 & 5.9 \\
\hline \% Terrigen (Ti-norm.) ${ }^{(2)}$ & 76.6 & 9.6 & 84.4 & 8.4 & 83.8 & 6.2 \\
\hline$[\mathrm{Ti}](\mu \mathrm{mol} \mathrm{g}-1)$ & 86.4 & 10.9 & 95.2 & 9.5 & 94.5 & 7.0 \\
\hline$[\mathrm{Fe}]\left(\mu \mathrm{mol} \mathrm{g}{ }^{-1}\right)$ & 762 & 112 & 792 & 96 & 740 & 90 \\
\hline [Al] $\left(\mu \mathrm{mol} \mathrm{g}{ }^{-1}\right)$ & 2578 & 316 & 2751 & 227 & 2783 & 185 \\
\hline
\end{tabular}




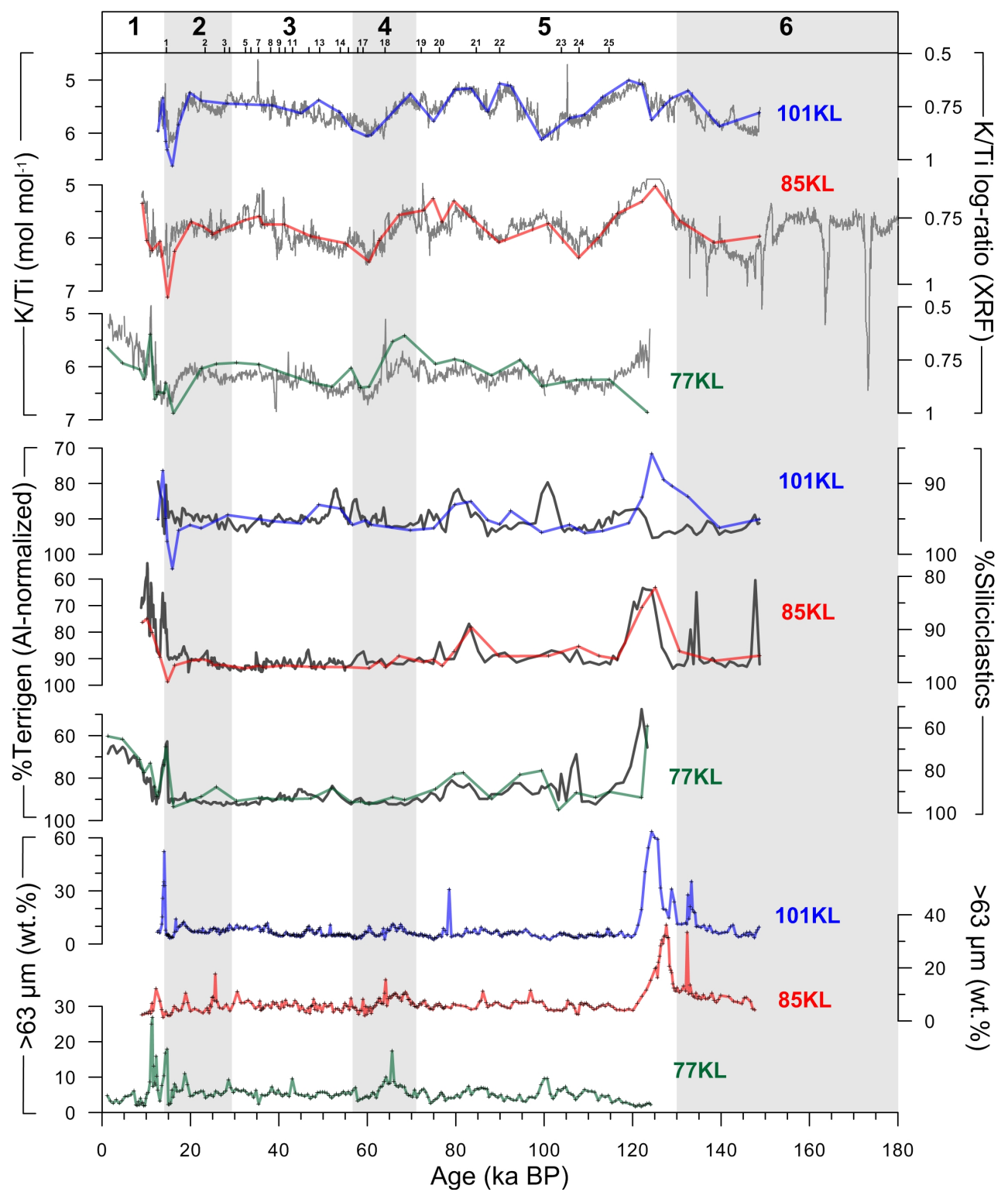

Fig. 8. Records approximating changes in terrigenous matter supply over the past $180 \mathrm{kyr}$. Relative contents of coarse material ( $>63 \mu \mathrm{m})$, terrigenous matter (normalized to Al concentrations of continental crust; Taylor and McLennan, 1995), and molar K/Ti ratios (colored lines), in comparison to relative amounts of siliciclastics, and XRF K/Ti log-ratios (underlying grey lines) for cores SO201-2-77KL (green lines), $-85 \mathrm{KL}$ (red lines), and -101KL (blue lines). Note that all y-axes are inverted, except for $>63 \mu \mathrm{m}$.

the accumulation of siliciclastic material (AR $\mathrm{Asiliciclastics})$, and therefore by changes in terrigenous matter supply (Fig. 4). Accordingly, cold intervals (MIS 6, 5.4, 5.2, 4 to 2) are characterized by high terrigenous matter supply, whereas warm intervals (MIS 5.5, 5.3, 5.1, and 1) show reduced proxy concentrations or ratios. Notably, a meridional gradient in $\mathrm{AR}_{\text {Silciclastics }}$ is observed along the core transect with lower values and therefore potentially decreasing terrigenous matter supply toward the southernmost site (Fig. 4). The most pronounced minima in the proxy records are found during interglacials. In core $77 \mathrm{KL}$ higher amounts of $>63 \mu \mathrm{m}$ and of $\mathrm{CaCO}_{3}$ concentrations (XRF $\mathrm{Ca} / \mathrm{Ti}$ log-ratios) occur synchronously, indicating that changes in $\mathrm{CaCO}_{3}$ result from higher foraminiferal abundances. Although independently derived, covariation is also found between \%Terrigen and $\%$ Siliciclastics, which are characterized by almost identical ranges (Fig. 8, Table 3).

$\mathrm{K} / \mathrm{Ti}$ ratios show a range of $5-7 \mathrm{~mol} \mathrm{~mol}^{-1}$ in all cores (Fig. 8, Table 3). We consider this ratio to be indicative of changes in the geochemical composition of the terrigenous matter itself. During MIS 5.5 and the Holocene, \%Siliciclastics are reduced to $\sim 50 \%$ at Site $77 \mathrm{KL}, \sim 60 \%$ at 


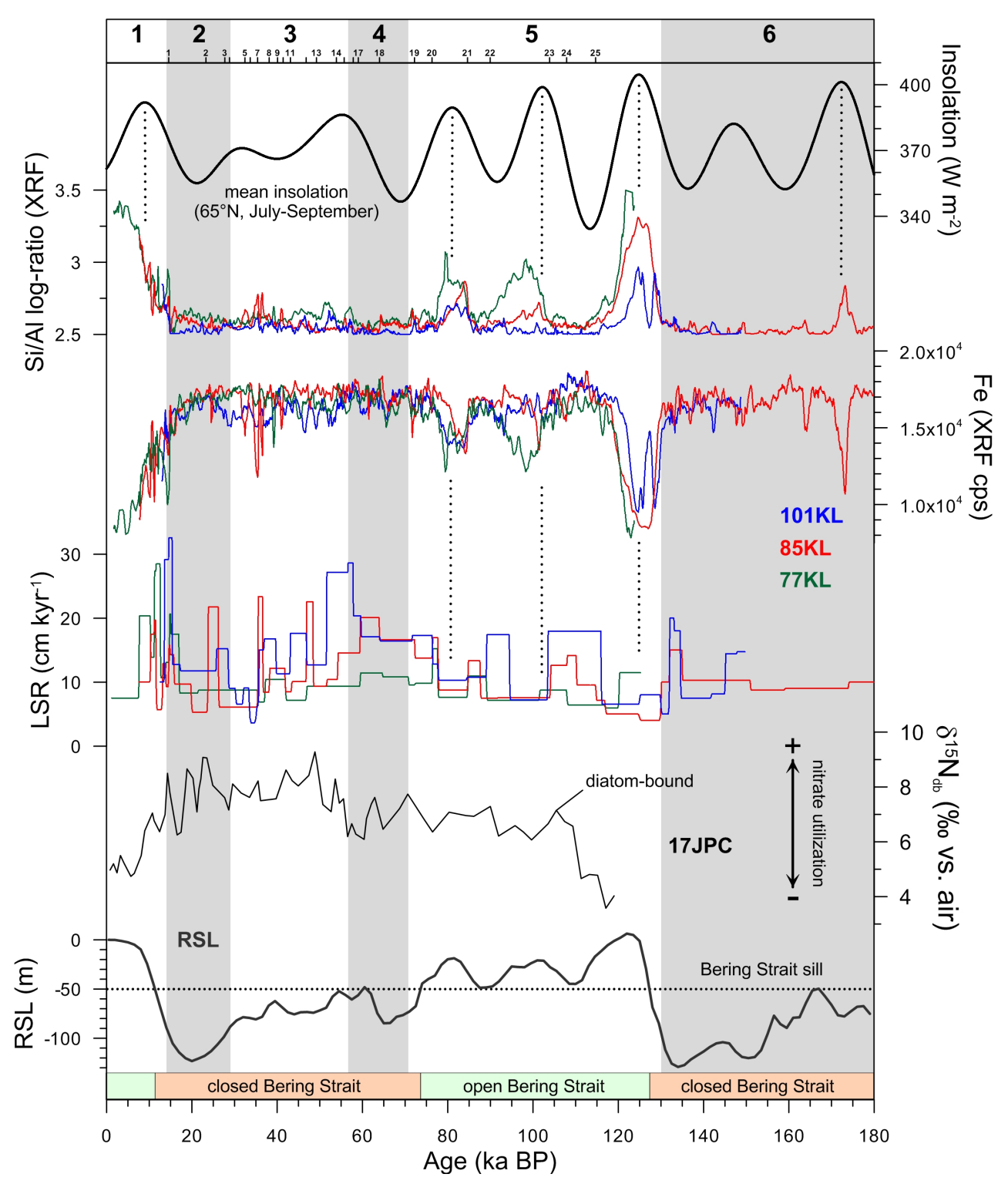

Fig. 9. Records of XRF Si/Al log-ratios reflecting changes in biogenic opal concentrations (marine productivity), XRF records of Fe (in cps) reflecting relative changes in terrigenous matter supply, and linear sedimentation rates (LSR) at sites SO201-2-77KL (green lines), -85KL (red lines), and -101KL (blue lines) for the last $180 \mathrm{kyr}$. Logging data are smoothed by 5-point-running averages. Relative sea level (RSL) is after Waelbroeck et al. (2002). The dashed horizontal line indicates the sill depth of the Bering Strait ( $\sim 50 \mathrm{~m})$. Summer insolation at $65^{\circ} \mathrm{N}$ (July-August) was calculated after Laskar et al. (2004). Records of diatom-bound nitrogen isotope ratios $\left(\delta^{15} \mathrm{~N}_{\mathrm{db}}\right)$, assumed to reflect changes in nitrate utilization, are shown for Bowers Ridge core 17JPC (Brunelle et al., 2007). Comparison of these records suggests that marine productivity and terrigenous matter supply are subject to external forcing by summer insolation and sea-level changes.

Site $85 \mathrm{KL}$, and $\sim 70 \%$ at Site $101 \mathrm{KL}$. At the same time, $\mathrm{K} / \mathrm{Ti}$ ratios decrease to $\sim 5 \mathrm{~mol} \mathrm{~mol}^{-1}$. Minor drops were recorded during MIS 5.3 and $5.1(\sim 15 \%$ in siliciclastics; $\sim 0.5 \mathrm{~mol} \mathrm{~mol}^{-1}$ in $\mathrm{K} / \mathrm{Ti}$ ), whereas $\mathrm{K} / \mathrm{Ti}$ ratios increased by $\sim 1 \mathrm{~mol} \mathrm{~mol}^{-1}$ during MIS 4 and subsequently decreased during MIS 3. In core 85KL MIS 6 is characterized by short-lived maxima in XRF K/Ti log-ratios at $\sim 173$ and $\sim 163 \mathrm{ka} \mathrm{BP}$. This core and core $101 \mathrm{KL}$ also reveal a minor peak in $>63 \mu \mathrm{m}$ found at $\sim 133 \mathrm{ka} \mathrm{BP}$, which occurs simul- taneously with minima in \%Siliciclastics but with maxima in $\mathrm{CaCO}_{3}$ and TOC. Notably, highest amounts of $>63 \mu \mathrm{m}$ were recorded at sites $85 \mathrm{KL}$ and $101 \mathrm{KL}$ at the end of Termination II ( $\sim 127-125 \mathrm{ka} \mathrm{BP})$ with maxima of $\sim 30 \%$ and $\sim 60 \%$, respectively. These maxima are concurrent with high $[\mathrm{C} / \mathrm{N}] \mathrm{a}$ ratios and lead maxima in TOC and opal concentrations by $\sim 3 \mathrm{kyr}$. During Termination I, the B/A is characterized by reductions in \% Siliciclastics and \% Terrigen of up to $\sim 25 \%$ and of up to $\sim 0.5 \mathrm{~mol} \mathrm{~mol}^{-1}$ in K/Ti. Maxima 
in $>63 \mu \mathrm{m}$ were recorded during both, the $\mathrm{B} / \mathrm{A}$ and the PB. During HS1 maxima in K/Ti are observed, and during the YD all proxies briefly return to glacial values, followed by a gradual decrease into the Holocene. The described proxy ranges and their temporal variability almost compare to those reported for the central Okhotsk Sea (Nürnberg and Tiedemann, 2004), which showed lower interglacial minima in $\%$ Siliciclastics of $\sim 35 \%$.

In all cores from Shirshov Ridge linear relationships between concentrations of lithogenous elements $\mathrm{Al}, \mathrm{Fe}$, and Ti were found (Fig. 7). This indicates that these elements originate from the same geochemical source and/or share the same transport mechanism. [Al] correlated with \%Siliciclastics in cores $77 \mathrm{KL}\left(R^{2}=0.42\right)$ and $85 \mathrm{KL}\left(R^{2}=0.74\right)$, but not in core $101 \mathrm{KL}\left(R^{2}=0.08\right)$. We consider an influence of scavenging by organic material and/or bottom sediment resuspension on [Al] (Orians and Bruland, 1986; Nameroff et al., 2004) insignificant, which is supported by low interglacial concentrations and $\mathrm{Al} / \mathrm{Ti}$ ratios that are close to crustal values. Records for [Al], [Fe], and [Ti] follow the same temporal evolution described for the terrigenous proxies with general high values during most of the last $180 \mathrm{kyr}$ ( 2600-2800 $\mu \mathrm{mol} \mathrm{g} \mathrm{g}^{-1}$ for [Al], $\sim 700-900 \mu \mathrm{mol} \mathrm{g}^{-1}$ for $[\mathrm{Fe}], \sim 90-100 \mu \mathrm{mol} \mathrm{g} \mathrm{g}^{-1}$ for [Ti]) (Table 3). During MIS 5.5 and the Holocene [Al], [Fe], and [Ti] decreased by up to $\sim 800 \mu \mathrm{mol} \mathrm{g}^{-1}, \sim 300 \mu \mathrm{mol} \mathrm{g}{ }^{-1}$, and $\sim 30 \mu \mathrm{mol} \mathrm{g}^{-1}$, respectively. Notably, from MIS 3 to 1 [Fe] became slightly higher in core 77KL than in the other cores (Fig. 7). The described temporal evolution overall compares to that recorded in sediment cores from the central Okhotsk Sea (Sato et al., 2002) and the Antarctic Zone of the Southern Ocean (Latimer and Filippelli, 2001), except that the respective studies reported on glacial $[\mathrm{Al}]$ and [Ti] that were by $\sim 30 \%$ lower than those recorded at Shirhov Ridge. Moreover, these studies described very low interglacial values $\left(\sim 100 \mu \mathrm{mol} \mathrm{g} \mathrm{g}^{-1}\right.$ for $[\mathrm{Al}], \sim 100 \mu \mathrm{mol} \mathrm{g}^{-1}$ for $[\mathrm{Fe}], \sim 10-20 \mu \mathrm{mol} \mathrm{g}^{-1}$ for [Ti]) not found at our sites. This argues that the interglacial reduction in terrigenous fluxes at Shirshov Ridge was on the order of $\sim 30-40 \%$.

\subsubsection{Geochemical signature}

Molar $\mathrm{Al} / \mathrm{Ti}$ and $\mathrm{Fe} / \mathrm{Al}$ ratios were used to characterize the geochemical signature of the sediments from Shirshov Ridge. In general, $\mathrm{Al} / \mathrm{Ti}$ and $\mathrm{Fe} / \mathrm{Al}$ ratios remained fairly constant during the last $180 \mathrm{kyr}$ with similar ranges at all sites. Only at the end of both glacial terminations minor increases in $\mathrm{Al} / \mathrm{Ti}$ and minor decreases in $\mathrm{Fe} / \mathrm{Al}$ are found. Distinct glacial-interglacial differences are not observed, indicating that the source of the terrigenous matter or its underlying transport mechanism did not change. This is an interesting result, since records of \%Siliciclastics, \%Terrigen, and lithogenous element concentrations are characterized by strong variations on the glacial-interglacial level. $\mathrm{Al} / \mathrm{Ti}$ ratios varied between $22-34\left(\mathrm{~mol} \mathrm{~mol}^{-1}\right)$, with short-lived in-
Table 4. Ranges, averages and variability of molar elemental ratios in cores SO201-2-77KL, -85KL, and -101KL.

\begin{tabular}{lrrrrrr}
\hline & \multicolumn{2}{c}{$\mathrm{SO} 201-2-77 \mathrm{KL}$} & \multicolumn{2}{c}{$\mathrm{SO} 201-2-85 \mathrm{KL}$} & \multicolumn{2}{c}{$\mathrm{SO} 201-2-101 \mathrm{KL}$} \\
\hline & $\mathrm{Al} / \mathrm{Ti}$ & $\mathrm{Fe} / \mathrm{Al}$ & $\mathrm{Al} / \mathrm{Ti}$ & $\mathrm{Fe} / \mathrm{Al}$ & $\mathrm{Al} / \mathrm{Ti}$ & $\mathrm{Fe} / \mathrm{Al}$ \\
\hline Average & 29.9 & 0.30 & 29.0 & 0.29 & 29.5 & 0.26 \\
StDev. & 1.5 & 0.03 & 1.5 & 0.02 & 1.2 & 0.02 \\
Maximum & 34.1 & 0.34 & 32.3 & 0.36 & 32.4 & 0.30 \\
Minimum & 24.9 & 0.17 & 22.1 & 0.23 & 27.8 & 0.21 \\
\hline
\end{tabular}

creases $(\sim 3)$ at the end of MIS 4 , and during Terminations I and II. Average downcore Al/Ti values ( $\sim 29.5 \pm 3$; Table 4$)$, as well as surface sediment values from Shirshov Ridge $(29.4 \pm 4)$ and from the eastern Kamchatka continental margin (32.1 \pm 3$)$ (unpublished data) compare well, which indicates that past and modern sources of terrigenous matter are identical. These values are close to $\mathrm{Al} / \mathrm{Ti}$ ratios reported for Paleozoic $(\sim 29)$ and Mesozoic/Cenozoic shales $(\sim 32)$ from the Russian Platform (Ronov and Migdisov, 1971), but also compare with average values for sediment and continental crust ( 28; McLennan, 1995; Taylor and McLennan, 1995), river particulate and mud ( 30; McLennan, 1995), pelagic clay ( $\sim 32$; McLennan, 1995), as well as the range reported for loess deposits ( $\sim 26-31$; Taylor et al., 1983; Pye, 1987; McLennan, 1995). Values are clearly lower than that of the North American shale composite $(\sim 38$; Gromet et al., 1984), but higher than Al/Ti ratios of oceanic tholeiitic basalt ( 17; Engel et al., 1965) and surface samples from St. George Basin, SE Bering Sea ( 24; Gardner et al., 1980). Nürnberg and Tiedemann (2004) reported a different range for sediments from the central Okhotsk Sea $(\sim 24-45)$.

The downcore $\mathrm{Fe} / \mathrm{Al}$ ratios varied between $0.17-0.36$ (mol $\mathrm{mol}^{-1}$ ) (Table 4). This range is also found in surface sediment samples from Shirshov Ridge (0.22-0.39; unpublished data), and it is in agreement with downcore results from the central Okhotsk Sea $(0.28 \pm 0.03$; Nürnberg and Tiedemann, 2004). Our Fe/Al ratios compare to those reported for the North American shale composite and average mud $(\sim 0.24$; Gromet et al., 1984; McLennan, 1995), Mesozoic/Cenozoic $(\sim 0.26)$ and Paleozoic $(\sim 0.28)$ Russian Platform shales (Ronov and Migdisov, 1971), average values for river particulate $(\sim 0.25)$ and sediment $(\sim 0.27)$ (McLennan, 1995). Oceanic tholeiitic basalt $(\sim 0.28$; Engel et al., 1965$)$ and surface samples from St. George Basin ( 0.28; Gardner et al., 1980) also apply to the overall range. The value for bulk continental crust is higher $(\sim 0.41$; Taylor and McLennan, 1995), while loess deposits show a lower range between 0.17-0.25 (Taylor et al., 1983; Pye, 1987; McLennan, 1995). From these results we conclude that sediments from Shirshov Ridge represent a mixture of geochemical signatures from aeolian sediments (loess) and continental sources that are supposedly not influenced by North American shales. 


\subsubsection{Transport mechanism and source area}

Possible mechanisms of terrigenous matter transport encompass aeolian and fluvial supply, as well as sea-ice rafting. Wind transported aerosols present in $\mathrm{N}$ Pacific sediments are restricted to the vicinity of their respective source area, which in our case are most likely situated in NE Siberia. Model results of global desert dust deposition show fluxes of $0.5-1.0 \mathrm{~g} \mathrm{~m}^{-2} \mathrm{yr}^{-1}$ for the Bering Sea (Mahowald et al., 2005), which implies that today aeolian input is negligible. This seems to have been different during past cold intervals as indicated by our higher lithogenous element concentrations and generally enhanced glacial dust fluxes (e.g. Ruth et al., 2003). Major rivers entering the Bering Sea are the Yukon and Anadyr rivers, which are situated at rather long distances from Shirshov Ridge (cf. Fig. 1). Today the Yukon River provides $\sim 63 \%$ of the total sediment load to the Bering Sea and it is suggested that glacial sediments from the Meiji Drift, NW Pacific, contain a larger fraction of terrigenous material delivered from Yukon-Bering Sea sources (VanLaningham et al., 2009). Surface sediments from the eastern Bering Sea shelf consist of Yukon River-derived detrital material (Asahara et al., 2012; Nagashima et al., 2012). Yet it remains unclear how the terrigenous material is transported from the eastern Bering Sea shelf to the Meiji Drift in the NW Pacific. We suggest that sea ice plays a considerable role in transporting terrigenous matter toward Shirshov Ridge, although we can not exclude a significant contribution from suspension load carried by the BSC. For the Arctic, Nürnberg et al. (1994) reported on sediments entrained in sea ice to be generally fine grained (clayey silts, silty clays) and mainly composed of quartz, clay minerals and diatom flora. Sediments from the central Okhotsk Sea, which are also assumed to originate from sea-ice rafting are described as mainly clay and silt-sized siliciclastics ( $>65 \%$ siliciclastics) featuring dropstones $(3-5 \mathrm{~cm})$, and various lithogenic components (mainly quartz, rock fragments, mica, and dark minerals), with regionally different ice-rafted debris (IRD) composition (Nürnberg and Tiedemann, 2004; Nürnberg et al., 2011). This sedimentary composition is similar to that found in sediments recovered from Shirshov Ridge, although IRD records are needed for verification. Since dropstones are rather uncommon in our cores, which, if present, appear as well-rounded pebbles, and due to the dominance of silt- and clay-sized terrigenous material we suggest a beach deposit origin and tidal pumping, suspension freezing and beach-ice formation to be responsible for the entrainment of terrigenous matter into newly formed sea ice.

The influence of ice in the Bering Sea realm during glacials, either in the form of icebergs or sea ice is still debated. Kaufman et al. (1996) suggested that the most recent major ice advance in SW Alaska occurred between $\sim 90-75 \mathrm{ka}$ BP. For MIS 3 Bigg et al. (2008) proposed a Kamchatka-Koryak Ice Sheet with marine-terminating ice margins. Our cores lack clear evidence for iceberg discharge at $\sim 40 \mathrm{ka} \mathrm{BP}$ (Bigg et al., 2008), therefore not supporting their suggested iceberg migration paths. For the LGM, the presence of the Beringian Ice Sheet (e.g. Grosswald and Hughes, 2002) has been disproved (e.g. Brigham-Grette et al., 2001, 2003; Karhu et al., 2001), and Kamchatkan climate seems to have been too arid for the development of large continental ice sheets during that time (Barr and Clark, 2011). We therefore favor sea ice over iceberg transport.

Lisitzin (2002) identified mineralogical provinces for western Bering Sea surface sediments together with their possible migration paths and proposed that coarse silts and the larger grain size fractions (pebbles, gravel, boulder) are controlled by sea ice, sharing the same provinces and transport pathways. Accordingly, the Koryak Coast, Olyutorskii Bay, and northern Kamchatka provinces (cf. Fig. 1) are potential source areas for the ice-rafted material. Anadyr Bay, where modern seasonal sea-ice formation begins during fall, is as well taken into consideration. The $\mathrm{K} / \mathrm{Ti}$ ratio is assumed to reflect temporal changes in sediment sources weathered from acidic (more $\mathrm{K}$ ) and basaltic (more Ti) source rocks (Richter et al., 2006). Relatively increased K/Ti ratios are observed at times of enhanced terrigenous matter supply. If sea-ice rafting is the main driver of these changes, the geochemical source of the terrigenous matter (and consequently the ice-rafted material) would be characterized as being relatively increased in $\mathrm{K}$. Of the considered provinces only Anadyr Bay is reported to contain acidic index rocks (Lisitzin, 2002), although geochemical data to clearly identify it as the proposed source area of Shirshov Ridge sediments do not exist. That the source area supposedly lies in the vicinity of Anadyr Bay is supported by the finding that interannual variability in Bering Sea ice cover is controlled by wind-driven ice mass advection, which is clearly southwestward from there (Zhang et al., 2010). However, although stronger ocean/bottom currents can not be excluded as potential transport mechanism for the detrital fractions, the available data seem to congruently argue for a source area that is located on the eastern Bering Sea shelf (VanLaningham et al., 2009; Asahara et al., 2012; Nagashima et al., 2012).

\subsection{Environmental changes during the last $180 \mathrm{kyr}$}

\subsubsection{Glacial situation}

Cold intervals of the last $180 \mathrm{kyr}$ seem to have been subject to strongly reduced, but maintained export production at our sites. At the same time, our records indicate high input of terrigenous matter, which is in agreement with records from the Okhotsk Sea (Nürnberg and Tiedemann, 2004; Nürnberg et al., 2011). Although regionally different, low glacial export production characterized the whole $\mathrm{N}$ Pacific during the last $800 \mathrm{kyr}$ (for a review see Kienast et al., 2004). Nürnberg et al. (2011) argued for extreme glacial ice conditions in the Okhotsk Sea during late MIS 6 with a potentially perennial ice coverage. From our results, we can not 
unambiguously argue for similar conditions during late MIS 6 , although the coarse fraction maxima found during Termination II might indicate the sudden melt of an expanded seaice cover that was perennial during the final phase of MIS 6. Glacial conditions in the Okhotsk Sea are supposed to be similar to the modern winter situation of a strong Siberian High and a weak Aleutian Low, thereby resulting in strong offshore, northerly winds (Nürnberg and Tiedemann, 2004; Nürnberg et al., 2011). This situation might as well apply to the Bering Sea and would have resulted in enhanced seaice formation during a generally colder climate, thereby explaining the higher LSR and terrigenous inputs. At Bowers Ridge, at least for MIS 3 and 2, colder subsurface temperatures are supported by low total numbers of planktonic foraminifera, dominated by polar species Neogloboquadrina pachyderma (sin.) and reduced/absent numbers of subpolar species Globigerina bulloides (Gorbarenko et al., 2005). A spatially extended sea-ice coverage fostered by a shortened summer season might have resulted in enhanced upperocean stratification and reduced nutrient supply to the euphotic zone. Since primary productivity is limited by temperature and nutrient availability, the prolonged sea-ice season during colder intervals in hand with stronger stratification would have consequently led to the reduction in export production observed at our sites. This should be reflected by more efficient nitrate utilization, and indeed, bulk sediment and diatom-bound nitrogen isotope ratios $\left(\delta^{15} \mathrm{~N}\right)$ recorded at Bowers Ridge (Brunelle et al., 2007) show higher glacial than interglacial values (Fig. 9), thereby confirming earlier assumptions of enhanced stratification in the glacial Bering Sea (Nakatsuka et al., 1995; Brunelle et al., 2007; Kim et al., 2011).

It has been speculated that the net inflow of Alaskan Stream waters into the Bering Sea was reduced at times when the Bering Strait and/or other Aleutian passes, like Unimak Pass, were closed due to lower glacial sea level, thereby affecting Beringian climate (Pushkar et al., 1999; Tanaka and Takahashi, 2005). During MIS 2, a strengthened Subarctic Front could have additionally led to a reduced inflow of warmer and nutrient-enriched Pacific surface waters (Gorbarenko et al., 2005). In consequence, nutrient supply to the Bering Sea should have been further reduced and have resulted in stronger nitrate utilization. The relative sea level (RSL) reconstruction of Waelbroeck et al. (2002) implies that the Bering Strait was closed during MIS 6, as well as in between MIS 4 and 2 (Fig. 9), while its last major re-opening occurred at 12-11 ka BP (Keigwin et al., 2006). RSL changes in the Bering Strait are predominantly controlled by eustatic changes and suggested to considerably influence deep convection in the N Atlantic (Hu et al., 2010). At Bowers Ridge $\delta^{15} \mathrm{~N}$ values are highest during MIS 3 and 2 (Fig. 9), supporting an influence of RSL on upper-ocean stratification and, hence, nitrate utilization in the Bering Sea. A closed Bering Strait has previously been suggested to have resulted in a low-salinity surface layer that reinforced vertical stratification in the Bering Sea (Sancetta, 1983).

The low glacial $\mathrm{CaCO}_{3}$ concentrations and abundances of oxic benthic foraminifera species point toward the presence of corrosive bottom waters as a result of organic matter degradation under oxic bottom water conditions (Kim et al., 2011). This implies that either $\mathrm{O}_{2}$-rich intermediate water masses were formed in the Bering Sea, or flew in from the Pacific side. Sea-ice formation in the Bering Sea due to brine rejection results in denser, $\mathrm{O}_{2}$-rich surface waters (e.g. Niebauer et al., 1999), and thus might have maintained the production and ventilation of intermediate water. Rella et al. (2012) reported on benthic $\delta^{18} \mathrm{O}$ excursions in sediments from the northern slope, which implies that the Bering Sea was a source of intermediate water during past stadial episodes, which is supported by microfossil assemblages (Ohkushi et al., 2003). However, as the modern origin of NPIW lies in the Okhotsk Sea (Yasuda, 1997) and during glacial stages a closed Bering Strait prevented inflow of surface waters from the Arctic Ocean (Takahashi, 1998, 1999), inflow from the $\mathrm{N}$ Pacific can not be ruled out.

\subsubsection{Deglacial situation}

During Termination I high export production but low terrigenous input is observed during the $\mathrm{B} / \mathrm{A}$ and $\mathrm{PB}$ warm phases, whereas the opposite situation occurred during the HS1 and YD cold phases. Remarkably, SST records from our sites mirror the deglacial SST evolution recorded in the N Atlantic, supporting quasi-synchronicity of Northern Hemisphere climate changes (Max et al., 2012). Our records suggest that the early deglacial phase was characterized by higher input of terrestrial-derived organic matter from flooded shelf areas as previously suggested for the Okhotsk and Bering seas (Ternois et al., 2001; Seki et al., 2003; Khim et al., 2010). Alternatively, organic matter preservation became better due to poorly oxygenated conditions at the sediment-water interface. Notably, at the northern slope similar changes were reported to have occurred $\sim 2 \mathrm{kyr}$ earlier (Khim et al., 2010). This time lag for increased terrestrial organic carbon input might indicate that the northern slope and Shirshov Ridge were supplied from different sources or by different mechanisms.

Our records indicate enhanced sea-ice influence during HS1 and the YD, which for our sites is supported by qualitative reconstructions of the sea-ice-related $\mathrm{IP}_{25}$ biomarker (Max et al., 2012) and by increasing abundances of the seaice-related diatom genus Nitzschia at Umnak Plateau (Cook et al., 2005). Like during previous cold intervals, marine productivity was restricted by lowered temperature. A sudden decrease in bulk sedimentary and diatom-bound $\delta^{15} \mathrm{~N}$ (Fig. 9) point to decreased nitrate utilization (Brunelle et al., 2007, 2010). However, this drop in $\delta^{15} \mathrm{~N}$ is not fully understood since higher nutrient supply due to stronger vertical mixing should have resulted in enhanced export 
production, which is not observed. Deglacial changes in ventilation/overturning in the $\mathrm{N}$ Pacific realm have been inferred from ventilation ages (Adkins and Boyle, 1997; Ahagon et al., 2003; Ohkushi et al., 2004; Galbraith et al., 2007; Sarnthein et al., 2007; Sagawa and Ikehara, 2008; Okazaki et al., 2010; Lund et al., 2011; Jaccard and Galbraith, 2013), foraminiferal isotope data (e.g. Matsumoto et al., 2002; Rella et al., 2012), as well as modeling studies (e.g. Okazaki et al., 2010; Chikamoto et al., 2012; Menviel et al., 2012). Notably, enhanced ventilation in the N Pacific during HS1 seems to have been restricted to $\sim 1400-2400 \mathrm{~m}$ depth (Jaccard and Galbraith, 2013), whereas the deep abyssal Pacific was better ventilated during the subsequent B/A (Galbraith et al., 2007). Hence, it was suggested that NPIW formation was more enhanced, that it reached deeper, and that its source might have shifted to the Bering Sea during HS1 and during other cold periods (e.g. Matsumoto et al., 2002; Ohkushi et al., 2003; Rella et al., 2012; Jaccard and Galbraith, 2013).

For the onset of the $\mathrm{B} / \mathrm{A}$, and to a lesser degree also the PB phase, our records imply enhanced marine productivity and the sudden release of IRD from melting sea ice. Similar observations regarding changes in marine productivity have previously been reported for the whole Bering Sea realm (Gorbarenko, 1996; Cook et al., 2005; Gorbarenko et al., 2005; Okazaki et al., 2005; Khim et al., 2010) and other parts of the N Pacific (Keigwin and Jones, 1990; Keigwin et al., 1992; Gorbarenko, 1996; Keigwin, 1998; Crusius et al., 2004; McKay et al., 2004; Okazaki et al., 2005; Gebhardt et al., 2008). Increasing insolation should have amplified the surface ocean warming and led to more dynamic ice conditions, northward propagating ice margins, and a prolonged sea-ice-free summer season. Indeed, recent alkenone- and $\mathrm{Mg} / \mathrm{Ca}$-based studies indicate rising SST, strengthened thermal mixed layer stratification (stronger seasonal contrasts), and the onset of coccolithophorid production during the B/A (Caissie et al., 2010; Max et al., 2012; Riethdorf et al., 2013). Enhanced surface freshening due to melting sea ice is supported by higher abundances of radiolarian species Rhizoplegma boreale (Kim et al., 2011), as well as brackish diatom species Paralia sulcata (Gorbarenko et al., 2005). A maximum in $\delta^{15} \mathrm{~N}$ values (Fig. 9) implies increased nitrate utilization or even denitrification (Brunelle et al., 2007, 2010; Khim et al., 2010). It might further be speculated, that the increase in marine productivity associated with reduced seaice formation resulted in organic matter supply exceeding its degradation at the seafloor (Kim et al., 2011). In consequence, bottom water conditions might have become dysoxic or anoxic, impeding benthonic life and favoring laminae formation. This notion would be in agreement with the formation of dysoxic or laminated sediments observed at oxygen minimum zone (OMZ) depths in the N Pacific and Bering Sea during the B/A and PB (van Geen et al., 2003; Cook, 2006, and references therein) and most probably was related to an intensification of the OMZ (Zheng et al., 2000). At the same time the respired carbon pool was obviously removed from the deep basin, which resulted in enhanced carbonate preservation due to a deepened lysocline, and to an increase in atmospheric $\mathrm{CO}_{2}$ (e.g. Galbraith et al., 2007).

Our records show that at sites $85 \mathrm{KL}$ and $101 \mathrm{KL}$ the deglacial development during Termination II does not resemble that of Termination I. Most notably, extremely high amounts of coarse material are found at the end of Termination II showing values that are not reached previously or later at any site. At the same time minor excursions toward lower Fe/Al but higher Al/Ti ratios were recorded, indicating a slightly different geochemical composition of the sediments. We attribute these results to the sudden release of IRD in response to strong melting of a potentially perennial ice coverage present during the final phase of MIS 6 in agreement with conditions proposed for the Okhotsk Sea (Nürnberg et al., 2011). Also, records of benthic $\delta^{18} \mathrm{O}$ do not follow the LR04 stack, which is indicative of a strong regional effect on the $\delta^{18} \mathrm{O}$ signal, for example by melting of continental ice sheets in the Bering Sea realm. This might, of course, also be the result of constraints in our age models during that time frame.

\subsubsection{Interglacial situation}

In contrast to the situation during cold intervals, interglacials, as well as warm MIS 5.3 and 5.1 were characterized by increased marine productivity and decreased terrigenous matter supply. Our records for Site 77KL better compare to those reported for Bowers Ridge, whereas records from sites $85 \mathrm{KL}$ and $101 \mathrm{KL}$ resemble those from the northern slope and the central Okhotsk Sea. Marine productivity as reflected by opal concentrations seems to have been higher during MIS 5.5 than during the Holocene. Interglacial $\mathrm{CaCO}_{3}$ concentrations remained at or close to glacial values, implying a similar bottom water calcite saturation state with limited carbonate preservation. The interglacial increase in marine productivity most probably resulted from warmer temperatures and reduced sea-ice formation during a prolonged summer season (stronger seasonal contrasts). However, our records imply a reduction of only $\sim 30-40 \%$ in terrigenous matter supply. Overall, records of XRF Si/Al log-ratios are in phase with mean summer insolation at $65^{\circ} \mathrm{N}$ (July-September; calculated after Laskar et al., 2004; Fig. 9), showing maxima during the warm intervals (MIS 5.5, 5.3, 5.1, and 1). This implies a dominant insolation forcing for environmental changes in the Bering Sea. At Bowers Ridge, $\delta^{15} \mathrm{~N}$ values are lowest during interglacials (Brunelle et al., 2007, 2010) and they also remain low during most of MIS 5 (Fig. 9). This indicates reduced nitrate utilization as a consequence of enhanced vertical mixing, which supplies sufficient amounts of nitrate from the subsurface nitrate pool into the euphotic zone. This situation might have been additionally influenced by an open Bering Strait and Unimak Pass, allowing for enhanced inflow of water masses from the Alaskan Stream and enhanced outflow of relatively fresh surface waters into 
the Arctic. Reduced sea-ice formation, but enhanced nutrient supply by stronger vertical mixing as a result of a strengthened Alaskan Stream and BSC during higher sea level has been proposed before (Gorbarenko et al., 2005; Okazaki et al., 2005; Kim et al., 2011). Accordingly, sea-level changes must be considered as additional forcing mechanism to explain the recorded environmental changes.

\subsubsection{Interstadial situation}

High-resolution core logging resulted in the detection of short-lived maxima in our color $\mathrm{b}^{*}$ and $\mathrm{XRF} \mathrm{Ca} / \mathrm{Ti} \log$-ratio records during MIS 6 to 3. Notably, these maxima and maxima in $>63 \mu \mathrm{m}$ occur simultaneously. Most peaks were detected in cores $85 \mathrm{KL}$ and $101 \mathrm{KL}$ within which they are characterized by only $1-3 \mathrm{~cm}$ sediment thickness corresponding to a duration of $\sim 100-300 \mathrm{yr}$. These changes in sediment composition seem to be related to D-O events (interstadials) registered in the NGRIP ice core. The most prominent peaks correspond to D-O events 7, 8, 12, 17-21, and 24 (Fig. 5), but events off the NGRIP record are found. We consider them as brief intervals of enhanced marine productivity, sudden sea-ice melt associated with the subsequent release of IRD, and a higher bottom water calcite saturation state. However, due to our stratigraphic approach, which relies on the NGRIP record, we can neither argue for nor against an inphase evolution between abrupt climate changes recorded in Greenland ice and western Bering Sea sediments. Sediment records from Bowers Ridge (Gorbarenko et al., 2005, 2010), the northern slope (Kim et al., 2011; Rella et al., 2012), as well as the NE Pacific (Behl and Kennett, 1996; Hendy and Kennett, 2000; Ortiz et al., 2004) also implied millennialscale climate changes connected to N Atlantic D-O events, especially during MIS 3. Similar features were detected in stalagmites from China (Wang et al., 2001, 2008), which indicates a Northern Hemisphere-wide acting atmospheric coupling that is related to the intensity of the East Asian monsoon. Kennett and Ingram (1995) proposed that such an atmospheric coupling mechanism directly affected the ventilation of NPIW. Accordingly, interstadials seem to have been characterized by weak ventilation of NPIW in combination with increased marine productivity (Behl and Kennett, 1996; Hendy and Kennett, 2000; Kim et al., 2011) and warmer SSTs (Gorbarenko et al., 2005). Recently, Kim et al. (2011) reported on D-O event-related brief episodes of high bulk $\delta^{15} \mathrm{~N}$ values at the northern slope, implying increased nitrate utilization/denitrification. These results to a lesser degree reflect conditions inferred for the $\mathrm{B} / \mathrm{A}$ warm phase and thus might point to the release of deep-sequestered $\mathrm{CO}_{2}$ during interstadials.

\section{Summary and conclusions}

From our results we propose scenarios for environmental change in the Bering Sea during glacial, deglacial, and interglacial times which compare to those previously suggested for the Okhotsk Sea. During the last $180 \mathrm{kyr}$, the Bering Sea paleoenvironment was characterized by closely interacting processes controlling marine productivity and terrigenous matter supply. External forcing is attributed to Northern Hemisphere summer insolation and sea-level changes controlling atmospheric circulation patterns, sea-ice dynamics and upper-ocean stratification. Marine productivity, dominated by diatoms, remained low during cold intervals (MIS 6, 5.4, 5.2, 4 to 2) when the Bering Strait was closed and summer insolation was weak. Increases occurred during warm intervals (MIS 5.5, 5.3, 5.1, and 1), when insolation was high and the Bering Strait was open. Sediments from Shirshov Ridge are dominated by terrigenous, siliciclastic material mainly bound to the fine fractions. Terrigenous matter supply was generally high, with reductions of up to $\sim 30$ $40 \%$ during interglacials. Changes in terrigenous matter supply and marine productivity occurred synchronously with negatively correlated proxy behavior due to the sedimentary dilution by the biogenic components. Terrigenous input was supposedly stronger toward the northernmost site, and sea ice is considered as the transport agent for terrigenous matter, limiting marine productivity during cold intervals. Sedimentary geochemical signatures are a mixture of aeolian and continental sources, indicating that Shirshov Ridge sediments most likely originate from material entrained on the eastern Bering Sea shelf. Especially for the last glacial termination our records support the notion of an atmospheric, Northern Hemisphere-wide acting climate coupling. The situation during the HS1 and YD cold phases compared to that of cold intervals with enhanced sea-ice rafting limiting marine productivity during a shortened summer season (weak seasonal contrasts). In contrast, the B/A and PB warm phases were characterized by enhanced marine productivity as a result of a prolonged summer season and reduced seaice influence (strong seasonal contrasts). At the same time, reduced ventilation of intermediate waters is in accordance with stronger nitrate utilization and better $\mathrm{CaCO}_{3}$ preservation indicative of a release of deep-sequestered $\mathrm{CO}_{2}$ to the atmosphere. Moreover, we found supporting evidence for the occurrence of abrupt environmental changes that are related to interstadials recorded in the NGRIP ice core. 
Table A1. Age-depth points for core SO201-2-77KL. Ages $<20 \mathrm{ka}$ BP and AMS- ${ }^{14} \mathrm{C}$ ages have been derived from Max et al. (2012) and calendar ages are given with $1 \sigma$-ranges (in ka BP).

\begin{tabular}{|c|c|c|c|}
\hline Core & Depth (cm) & Cal. Age (ka BP) & Approach \\
\hline SO201-2-77KL & 6 & $2.0^{(1)}$ & color $b^{*}$ vs. color $b^{*}(\mathrm{SO} 201-2-12 \mathrm{KL})$ \\
\hline SO201-2-77KL & 49 & $7.6^{(1)}$ & color b* vs. color b* (SO201-2-12KL) \\
\hline SO201-2-77KL & 103 & 10.3 & Carbonate Spike 1 \\
\hline SO201-2-77KL & 105.5 & - & AMS $-{ }^{14} \mathrm{C}$ dating $(10.05-10.15)^{(2)}$ \\
\hline SO201-2-77KL & 115.5 & - & AMS- ${ }^{14} \mathrm{C}$ dating $(11.17-11.22)^{(3)}$ \\
\hline SO201-2-77KL & 116 & 11.2 & Carbonate Spike 2 \\
\hline SO201-2-77KL & 126 & 11.6 & color b* vs. NGRIP \\
\hline SO201-2-77KL & 155.5 & 12.62 & AMS- ${ }^{14} \mathrm{C}$ dating (12.61-12.73) \\
\hline SO201-2-77KL & 168.5 & 13.83 & AMS- ${ }^{14} \mathrm{C}$ dating (13.82-13.97) \\
\hline SO201-2-77KL & 180.5 & 14.75 & AMS- ${ }^{14} \mathrm{C}$ dating (14.50-14.95) \\
\hline SO201-2-77KL & 187 & 15.1 & color b* vs. color b* $(85 \mathrm{KL})$ \\
\hline SO201-2-77KL & 221 & 17.0 & color b* vs. color $b^{*}(85 \mathrm{KL})$ \\
\hline SO201-2-77KL & 258 & 21.5 & $\mathrm{Ca} / \mathrm{Ti}$ vs. $\mathrm{Ca} / \mathrm{Ti}(85 \mathrm{KL})$ \\
\hline SO201-2-77KL & 381 & 35.5 & color b* vs. color b* $(85 \mathrm{KL})$ \\
\hline SO201-2-77KL & 393 & 37.2 & color b* vs. color b* $(85 \mathrm{KL})$ \\
\hline SO201-2-77KL & 443 & 42.0 & color b* vs. color b* $(85 \mathrm{KL})$ \\
\hline SO201-2-77KL & 478 & 46.9 & color b* vs. color $b^{*}(85 \mathrm{KL})$ \\
\hline SO201-2-77KL & 596 & 59.5 & color b* vs. color b* $(85 \mathrm{KL})$ \\
\hline SO201-2-77KL & 656 & 64.7 & $\mathrm{Ca} / \mathrm{Ti}$ vs. $\mathrm{Ca} / \mathrm{Ti}(85 \mathrm{KL})$ \\
\hline SO201-2-77KL & 722 & 70.8 & color b* vs. color b* $(85 \mathrm{KL})$ \\
\hline SO201-2-77KL & 736 & 72.3 & color b* vs. color b* $(85 \mathrm{KL})$ \\
\hline SO201-2-77KL & 777 & 76.4 & color b* vs. color b* $(85 \mathrm{KL})$ \\
\hline SO201-2-77KL & 796 & 77.7 & color b* vs. color b* $(85 \mathrm{KL})$ \\
\hline SO201-2-77KL & 849 & 84.7 & color b* vs. color b* $(85 \mathrm{KL})$ \\
\hline SO201-2-77KL & 898 & 89.1 & $\mathrm{Ca} / \mathrm{Ti}$ vs. $\mathrm{Ca} / \mathrm{Ti}(85 \mathrm{KL})$ \\
\hline SO201-2-77KL & 986 & 101.5 & $\mathrm{Ca} / \mathrm{Ti}$ vs. $\mathrm{Ca} / \mathrm{Ti}(85 \mathrm{KL})$ \\
\hline SO201-2-77KL & 1043 & 108.0 & color b* vs. color b* $(85 \mathrm{KL})$ \\
\hline SO201-2-77KL & 1100 & 116.9 & color b* vs. color b* $(85 \mathrm{KL})$ \\
\hline SO201-2-77KL & 1120 & 120.2 & color b* vs. color b* $(85 \mathrm{KL})$ \\
\hline SO201-2-77KL & 1166 & 124.2 & color b* vs. color b* $(85 \mathrm{KL})$ \\
\hline
\end{tabular}

(1) Uncertain age; (2) Used to define carbonate spike 1 (see Max et al., 2012); ${ }^{(3)}$ Used to define carbonate spike 2 (see Max et al., 2012).

\section{Appendix A}

\section{Age models}

Age-depth points for cores SO201-2-77KL, -85KL, and $-101 \mathrm{KL}$ are given in Tables A1, A2, and A3, respectively.

\section{Appendix B}

\section{Surface sediment samples}

Calculated results of $\mathrm{Ba}_{\text {bio }}, P_{\mathrm{New}}$, and PP from discrete XRF measurements conducted on surface sediment samples recovered in direct vicinity of the studied sediment cores using a MultiCorer (MUC) are given in Table B1. 
Table A2. Age-depth points for core SO201-2-85KL. Ages $<20 \mathrm{ka}$ BP and AMS- ${ }^{14} \mathrm{C}$ ages have been derived from Max et al. (2012) and calendar ages are given with $1 \sigma$-ranges (in ka BP).

\begin{tabular}{|c|c|c|c|}
\hline Core & Depth $(\mathrm{cm})$ & Cal. Age (ka BP) & Approach \\
\hline SO201-2-85KL & 1 & $7.6^{(1)}$ & color $b^{*}$ vs. color $b^{*}(\mathrm{SO} 201-2-12 \mathrm{KL})$ \\
\hline SO201-2-85KL & 26.5 & - & AMS- ${ }^{14} \mathrm{C}$ dating $(10.38-10.51)^{(2)}$ \\
\hline SO201-2-85KL & 28 & 10.3 & Carbonate Spike 1 \\
\hline SO201-2-85KL & 44 & 11.2 & Carbonate Spike 2 \\
\hline SO201-2-85KL & 45.5 & - & AMS- ${ }^{14} \mathrm{C}$ dating $(10.79-10.97)^{(3)}$ \\
\hline SO201-2-85KL & 52 & 11.6 & color b* vs. NGRIP \\
\hline SO201-2-85KL & 60.5 & 13.10 & AMS- ${ }^{14} \mathrm{C}$ dating (13.10-13.22) \\
\hline SO201-2-85KL & 70.5 & 13.87 & AMS- ${ }^{14} \mathrm{C}$ dating (13.67-13.89) \\
\hline SO201-2-85KL & 77 & 14.6 & color $b^{*}$ vs. NGRIP \\
\hline SO201-2-85KL & 82 & 14.9 & color b* vs. NGRIP \\
\hline SO201-2-85KL & 95.5 & 15.84 & AMS- ${ }^{14} \mathrm{C}$ dating (15.80-15.82) \\
\hline SO201-2-85KL & 135.5 & 19.90 & AMS- ${ }^{14} \mathrm{C}$ dating (19.58-19.90) \\
\hline SO201-2-85KL & 155.5 & 23.78 & AMS- ${ }^{14} \mathrm{C}$ dating (23.71-24.19) \\
\hline SO201-2-85KL & 209 & 26.2 & Transfer of AMS- ${ }^{14} \mathrm{C}$ age from core $101 \mathrm{KL}$, but not well constrained \\
\hline SO201-2-85KL & 266 & 35.5 & color b* vs. NGRIP \\
\hline SO201-2-85KL & 292 & 36.6 & color b* vs. NGRIP \\
\hline SO201-2-85KL & 305 & 38.2 & color b* vs. NGRIP \\
\hline SO201-2-85KL & 350 & 41.9 & RPI vs. PISO-1500 (Laschamp) \\
\hline SO201-2-85KL & 363 & 43.4 & color $b^{*}$ vs. NGRIP \\
\hline SO201-2-85KL & 398 & 46.9 & color b* vs. NGRIP \\
\hline SO201-2-85KL & 433 & 48.4 & color b* vs. NGRIP \\
\hline SO201-2-85KL & 463 & 51.7 & color b* vs. NGRIP \\
\hline SO201-2-85KL & 490 & 54.2 & color b* vs. NGRIP \\
\hline SO201-2-85KL & 567 & 59.5 & color b* vs. NGRIP \\
\hline SO201-2-85KL & 657 & 64.0 & color b* vs. NGRIP \\
\hline SO201-2-85KL & 675 & 65.0 & RPI vs. PISO-1500 (Norwegian-Greenland Sea) \\
\hline SO201-2-85KL & 796 & 72.3 & color b* vs. NGRIP \\
\hline SO201-2-85KL & 853 & 76.4 & color b* vs. NGRIP \\
\hline SO201-2-85KL & 876 & 77.8 & color b* vs. NGRIP \\
\hline SO201-2-85KL & 937 & 84.7 & color b* vs. NGRIP \\
\hline SO201-2-85KL & 976 & 87.7 & color b* vs. NGRIP \\
\hline SO201-2-85KL & 1006 & 91.7 & color b* vs. NGRIP \\
\hline SO201-2-85KL & 1100 & 104.1 & color b* vs. NGRIP \\
\hline SO201-2-85KL & 1149 & 108.0 & color b* vs. NGRIP \\
\hline SO201-2-85KL & 1180 & 110.2 & color b* vs. NGRIP \\
\hline SO201-2-85KL & 1210 & 113.3 & color b* vs. NGRIP \\
\hline SO201-2-85KL & 1224 & 114.8 & color b* vs. NGRIP \\
\hline SO201-2-85KL & 1240 & 117.0 & RPI vs. PISO-1500 (Blake) \\
\hline SO201-2-85KL & 1280 & 125.0 & color b* vs. Sanbao $\delta^{18} \mathrm{O}$ (MIS 5.5 climate optimum) \\
\hline SO201-2-85KL & 1300 & $130.0^{(4)}$ & SMP vs. LR04 (MIS 5/6 Boundary) \\
\hline SO201-2-85KL & 1320 & 132.0 & color b* vs. Sanbao $\delta^{18} \mathrm{O}(\mathrm{HE} 11)$ \\
\hline SO201-2-85KL & 1365 & 135.0 & color $\mathrm{b}^{*}, \mathrm{Ca} / \mathrm{Ti}$ vs. Sanbao $\delta^{18} \mathrm{O}$ \\
\hline SO201-2-85KL & 1530 & 151.0 & color $\mathrm{b}^{*}, \mathrm{Ca} / \mathrm{Ti}$ vs. Sanbao $\delta^{18} \mathrm{O}$ \\
\hline SO201-2-85KL & 1600 & 159.0 & RPI vs. PISO-1500 \\
\hline SO201-2-85KL & 1735 & $174.0^{(4)}$ & SMP vs. LR04 (MIS 6 Minimum) \\
\hline SO201-2-85KL & 1813 & $181.8^{(5)}$ & Extrapolation \\
\hline
\end{tabular}


Table A3. Age-depth points for core SO201-2-101KL. Ages $<20 \mathrm{ka} \mathrm{BP}$ and AMS- ${ }^{14} \mathrm{C}$ ages have been derived from Max et al. (2012) and calendar ages are given with $1 \sigma$-ranges (in ka BP).

\begin{tabular}{|c|c|c|c|}
\hline Core & Depth $(\mathrm{cm})$ & Cal. Age (ka BP) & Approach \\
\hline SO201-2-101KL & 4 & 12.9 & $\mathrm{Ca} / \mathrm{Ti}$ vs. $\mathrm{Ca} / \mathrm{Ti}(85 \mathrm{KL})$ \\
\hline SO201-2-101KL & 10.5 & 13.56 & AMS- ${ }^{14} \mathrm{C}$ dating $(13.69-13.84)$ \\
\hline SO201-2-101KL & 41 & 14.6 & color b* vs. NGRIP \\
\hline SO201-2-101KL & 67 & 15.4 & color b* vs. NGRIP \\
\hline SO201-2-101KL & 90.5 & 17.25 & AMS- ${ }^{14} \mathrm{C}$ dating $(17.17-17.51)$ \\
\hline SO201-2-101KL & 110.5 & 18.95 & AMS- ${ }^{14} \mathrm{C}$ dating $(19.54-19.92)$ \\
\hline SO201-2-101KL & 140 & 23.78 & Transfer of AMS- ${ }^{14} \mathrm{C}$ Age from Core $85 \mathrm{KL}$ \\
\hline SO201-2-101KL & 190.5 & 25.74 & AMS- ${ }^{14} \mathrm{C}$ dating $(25.88-26.35)$ \\
\hline SO201-2-101KL & 234 & 28.6 & color b* vs. NGRIP \\
\hline SO201-2-101KL & 249 & 30.3 & color b* vs. NGRIP \\
\hline SO201-2-101KL & 260.5 & 32.0 & AMS- ${ }^{14} \mathrm{C}$ dating $(32.12-33.54)$ \\
\hline SO201-2-101KL & 274 & 33.5 & $\mathrm{Ca} / \mathrm{Ti}$ vs. $\mathrm{Ca} / \mathrm{Ti}(85 \mathrm{KL})$ \\
\hline SO201-2-101KL & 280 & 35.1 & $\mathrm{Ca} / \mathrm{Ti}$ vs. $\mathrm{Ca} / \mathrm{Ti}(85 \mathrm{KL})$ \\
\hline SO201-2-101KL & 284 & 35.7 & $\mathrm{Ca} / \mathrm{Ti}$ vs. $\mathrm{Ca} / \mathrm{Ti}(85 \mathrm{KL})$ \\
\hline SO201-2-101KL & 302 & 36.9 & $\mathrm{Ca} / \mathrm{Ti}$ vs. $\mathrm{Ca} / \mathrm{Ti}(85 \mathrm{KL})$ \\
\hline SO201-2-101KL & 349 & 39.7 & $\mathrm{Ca} / \mathrm{Ti}$ vs. $\mathrm{Ca} / \mathrm{Ti}(85 \mathrm{KL})$ \\
\hline SO201-2-101KL & 387 & 43.1 & $\mathrm{Ca} / \mathrm{Ti}$ vs. $\mathrm{Ca} / \mathrm{Ti}(85 \mathrm{KL})$ \\
\hline SO201-2-101KL & 454 & 46.9 & $\mathrm{Ca} / \mathrm{Ti}$ vs. $\mathrm{Ca} / \mathrm{Ti}(85 \mathrm{KL})$ \\
\hline SO201-2-101KL & 514 & 51.6 & $\mathrm{Ca} / \mathrm{Ti}$ vs. $\mathrm{Ca} / \mathrm{Ti}(85 \mathrm{KL})$ \\
\hline SO201-2-101KL & 650 & 56.6 & $\mathrm{Ca} / \mathrm{Ti}$ vs. $\mathrm{Ca} / \mathrm{Ti}(85 \mathrm{KL})$ \\
\hline SO201-2-101KL & 685 & 57.8 & $\mathrm{Ca} / \mathrm{Ti}$ vs. $\mathrm{Ca} / \mathrm{Ti}(85 \mathrm{KL})$ \\
\hline SO201-2-101KL & 723 & 59.7 & $\mathrm{Ca} / \mathrm{Ti}$ vs. $\mathrm{Ca} / \mathrm{Ti}(85 \mathrm{KL})$ \\
\hline SO201-2-101KL & 799 & 64.1 & $\mathrm{Ca} / \mathrm{Ti}$ vs. $\mathrm{Ca} / \mathrm{Ti}(85 \mathrm{KL})$ \\
\hline SO201-2-101KL & 923 & 71.7 & $\mathrm{Ca} / \mathrm{Ti}$ vs. $\mathrm{Ca} / \mathrm{Ti}(85 \mathrm{KL})$ \\
\hline SO201-2-101KL & 1005 & 76.4 & color b* vs. color b* $(85 \mathrm{KL})$ \\
\hline SO201-2-101KL & 1023 & 77.8 & color b* vs. color b* $(85 \mathrm{KL})$ \\
\hline SO201-2-101KL & 1092 & 84.4 & $\mathrm{Ca} / \mathrm{Ti}$ vs. $\mathrm{Ca} / \mathrm{Ti}(85 \mathrm{KL})$ \\
\hline SO201-2-101KL & 1142 & 89.1 & $\mathrm{Ca} / \mathrm{Ti}$ vs. $\mathrm{Ca} / \mathrm{Ti}(85 \mathrm{KL})$ \\
\hline SO201-2-101KL & 1236 & 94.5 & color b* vs. color b* $(85 \mathrm{KL})$ \\
\hline SO201-2-101KL & 1301 & 103.5 & color b* vs. color b* $(85 \mathrm{KL})$ \\
\hline SO201-2-101KL & 1526 & 116.0 & Benthic $\delta^{18} \mathrm{O}$ vs. LR04 \\
\hline SO201-2-101KL & 1585 & 125.0 & color $\mathbf{b}^{*}$ vs. Sanbao $\delta^{18} \mathrm{O}$ (MIS 5.5 climate optimum) \\
\hline SO201-2-101KL & 1625 & 130.0 & $\mathrm{Ca} / \mathrm{Ti}$ vs. $\mathrm{Ca} / \mathrm{Ti}(85 \mathrm{KL})$ \\
\hline SO201-2-101KL & 1635 & 132.0 & color b* vs. Sanbao $\delta^{18} \mathrm{O}(\mathrm{HE} 11)$ \\
\hline SO201-2-101KL & 1657 & 133.1 & $\mathrm{Ca} / \mathrm{Ti}$ vs. $\mathrm{Ca} / \mathrm{Ti}(85 \mathrm{KL})$ \\
\hline SO201-2-101KL & 1684 & 134.6 & color $b^{*}$ vs. color b* $(85 \mathrm{KL})$ \\
\hline SO201-2-101KL & 1738 & 141.8 & $\mathrm{Ca} / \mathrm{Ti}$ vs. $\mathrm{Ca} / \mathrm{Ti}(85 \mathrm{KL})$ \\
\hline SO201-2-101KL & 1765 & 145.1 & color b* vs. color b* $(85 \mathrm{KL})$ \\
\hline SO201-2-101KL & 1804 & 147.8 & $\mathrm{Ca} / \mathrm{Ti}$ vs. $\mathrm{Ca} / \mathrm{Ti}(85 \mathrm{KL})$ \\
\hline SO201-2-101KL & 1832 & $149.7^{(1)}$ & Extrapolation \\
\hline
\end{tabular}

(1) By extrapolation using linear sedimentation rate (LSR).

Table B1. Site information, concentrations of $\mathrm{Ba}_{\mathrm{bio}}$, and calculated values for $P_{\mathrm{New}}$ and $\mathrm{PP}$ in surface sediment samples.

\begin{tabular}{lccrrrrr}
\hline Station & Latitude & Longitude & $\begin{array}{r}\text { Depth } \\
(\mathrm{mbsl})\end{array}$ & $\begin{array}{r}\text { Tube } \\
\text { Depth(cm) }\end{array}$ & $\begin{array}{r}\mathrm{Ba}_{\text {bio }}^{(1)} \\
(\mathrm{ppm})\end{array}$ & $\begin{array}{r}P_{\mathrm{New}}^{(2)} \\
\left(\mathrm{gC} \mathrm{m}^{-2} \mathrm{yr}^{-1}\right)\end{array}$ & $\begin{array}{c}\mathrm{PP}^{(3)} \\
\left(\mathrm{gC} \mathrm{m}^{-2} \mathrm{yr}^{-1}\right)\end{array}$ \\
\hline SO201-2-76MUC & $56^{\circ} 19.80^{\prime} \mathrm{N}$ & $170^{\circ} 41.96^{\prime} \mathrm{E}$ & 2137 & $1-2$ & 932 & 31.8 & 113 \\
SO201-2-76MUC & $56^{\circ} 19.80^{\prime} \mathrm{N}$ & $170^{\circ} 41.96^{\prime} \mathrm{E}$ & 2137 & $2-3$ & 1327 & 54.0 & 147 \\
SO201-2-76MUC & $56^{\circ} 19.80^{\prime} \mathrm{N}$ & $170^{\circ} 41.96^{\prime} \mathrm{E}$ & 2137 & $3-4$ & 1319 & 53.5 & 146 \\
SO201-2-83MUC & $57^{\circ} 30.28^{\prime} \mathrm{N}$ & $170^{\circ} 24.82^{\prime} \mathrm{E}$ & 970 & $0-1$ & 636 & 19.2 & 88 \\
SO201-2-83MUC & $57^{\circ} 30.28^{\prime} \mathrm{N}$ & $170^{\circ} 24.82^{\prime} \mathrm{E}$ & 970 & $1-2$ & 681 & 21.3 & 92 \\
SO201-2-99MUC & $58^{\circ} 52.53^{\prime} \mathrm{N}$ & $170^{\circ} 41.48^{\prime} \mathrm{E}$ & 643 & $2-3$ & 177 & 2.9 & 34 \\
\hline
\end{tabular}

(1) Via Al using the global average Ba/Al of pelitic rocks of $6.5 \mathrm{mg} \mathrm{g}^{-1}$ (Wedepohl, 1971). (2) After Nürnberg (1995) using an average $\mathrm{AR}_{\mathrm{Bulk}}$ of $4 \mathrm{~g} \mathrm{~cm}^{-2} \mathrm{kyr}^{-1}$. (3) After Eppley and Peterson (1979). 
Acknowledgements. This study resulted from the German-Russian joint research project KALMAR, funded by the German Ministry of Education and Research (BMBF), grant nos. 03G0672A and B. We thank the captain and crew of R/V Sonne cruise SO201-KALMAR Leg 2 for their professional support in recovering high-quality cores. Technical support and laboratory assistance came from B. Domeyer, N. Gehre, L. Haxhiaj, P. Appel, and J. Heinze and is gratefully acknowledged. E. Maier (AWI-Bremerhaven) conducted additional opal measurements for core 77KL. A. Matul (Shirshov Institute of Oceanology, Moscow) provided additional benthic foraminiferal tests to improve oxygen isotope stratigraphy for cores $85 \mathrm{KL}$ and $101 \mathrm{KL}$. We thank Luc Beaufort and two anonymous reviewers whose constructive reviews helped to considerably improve this article. The data are available via the PANGAEA Data Publisher for Earth \& Environmental Science (http://doi.pangaea.de/10.1594/PANGAEA.786307).

The service charges for this open access publication have been covered by a Research Centre of the Helmholtz Association.

Edited by: L. Beaufort

\section{References}

Adkins, J. F. and Boyle, E. A.: Changing atmospheric $\Delta^{14} \mathrm{C}$ and the record of deep water paleoventilation ages, Paleoceanography, 12, 337-344, 1997.

Ahagon, N., Ohkushi, K., Uchida, M., and Mishima, T.: Mid-depth circulation in the northwest Pacific during the last deglaciation: Evidence from foraminiferal radiocarbon ages. Geophys. Res. Lett., 30, 2097, doi:10.1029/2003GL018287, 2003.

Arzhanova, N. V., Zubarevich, V. L., and Sapozhnikov, V. V.: Seasonal variability of nutrient stocks in the euphotic zone and assessment of primary production in the Bering Sea, in: Complex studies of the Bering Sea ecosystem, edited by: Kotenev, B. N. and Sapozhnikov, V. V., VNIRO, Moscow, 162-179, 1995.

Asahara, Y., Takeuchi, F., Nagashima, K., Harada, N., Yamamoto, K., Oguri, K., and Tadai, O.: Provenance of terrigenous detritus of the surface sediments in the Bering and Chukchi Seas as derived from $\mathrm{Sr}$ and $\mathrm{Nd}$ isotopes: Implications for recent climate change in the Arctic regions, Deep-Sea Res. Pt. II, 61-64, 155171, doi:10.1016/j.dsr2.2011.12.004, 2012.

Bareille, G., Grousset, F. E., Labracherie, M., Labeyrie, L. D., and Petit, J.-R.: Origin of detrital fluxes in the southeast Indian Ocean during the last climatic cycles, Paleoceanography, 9, 799-819, 1994.

Barr, I. D. and Clark, C. D.: Glaciers and climate in Pacific Far NE Russia during the Last Glacial Maximum, J. Quaternary Sci., 26, 227-237, doi:10.1002/jqs.1450, 2011.

Behl, R. J. and Kennett, J. P.: Brief interstadial events in the Santa Barbara basin, NE Pacific, during the past $60 \mathrm{kyr}$, Nature, 379, 243-246, 1996.

Bigg, G. R., Clark, C. D., and Hughes, A. L. C.: A last glacial ice sheet on the Pacific Russian coast and catastrophic change arising from coupled ice-volcanic interaction, Earth Planet. Sci. Lett., 265, 559-570, doi:10.1016/j.epsl.2007.10.052, 2008.

Blockley, S. P. E., Lane, C. S., Hardiman, M., Rasmussen, S. O., Seierstad, I. K., Steffensen, J. P., Svensson, A., Lotter,
A. F., Turney, C. S. M., Ramsey, C. B., and INTIMATE members: Synchronisation of palaeoenvironmental records over the last 60,000 years, and an extended INTIMATE event stratigraphy to 48,000 b2k, Quaternary Sci. Rev., 36, 2-10, doi:10.1016/j.quascirev.2011.09.017, 2012.

Boyle, E. A.: Chemical accumulation variations under the Peru current during the past 130,000 years, J. Geophys. Res., 88, 76677680, 1983.

Brigham-Grette, J., Hopkins, D. M., Ivanov, V. F., Basilyan, E. B., Benson, S. L., Heiser, P. A., and Pushkar, V. S.: Last Interglacial (isotope stage 5) glacial and sea-level history of coastal Chukotka Peninsula and St. Lawrence Island, Western Beringia, Quaternary Sci. Rev., 20, 419-436, 2001.

Brigham-Grette, J., Gualtieri, L. M., Glushkova, O. Y., Hamilton, T. D., Mostoller, D., and Kotov, A.: Chlorine-35 and ${ }^{14} \mathrm{C}$ chronology support a limited last glacial maximum across central Chukotka, northeastern Siberia, and no Beringian ice sheet, Quaternary Res., 59, 386-398, doi:10.1016/S0033-5894(03)000589, 2003.

Broecker, W. S. and Peng, T.-H.: The role of $\mathrm{CaCO}_{3}$ compensation in the glacial to interglacial atmospheric $\mathrm{CO}_{2}$ change, Global Biogeochem. Cy., 1, 15-29, 1987.

Brunelle, B. G., Sigman, D. M., Cook, M. S., Keigwin, L. D., Haug, G. H., Plessen, B., Schettler, G., and Jaccard, S. L.: Evidence from diatom-bound nitrogen isotopes for subarctic $\mathrm{Pa}$ cific stratification during the last ice age and a link to North Pacific denitrification changes, Paleoceanography, 22, PA1215, doi:10.1029/2005PA001205, 2007.

Brunelle, B. G., Sigman, D. M., Jaccard, S. L., Keigwin, L. D., Plessen, B., Schettler, G., Cook, M. S., and Haug, G. H.: Glacial/interglacial changes in nutrient supply and stratification in the western subarctic North Pacific since the penultimate glacial maximum, Quaternary Sci. Rev., 29, 2579-2590, doi:10.1016/j.quascirev.2010.03.010, 2010.

Burov, B. V., Nourgaliev, D. K., and Iassonov, P. G.: Paleomagnetic analysis, Kazan University Press, Kazan, 167 pp., 1986 (in Russian).

Caissie, B. E., Brigham-Grette, J., Lawrence, K. T., Herbert, T. D., and Cook, M. S.: Last Glacial Maximum to Holocene sea surface conditions at Umnak Plateau, Bering Sea, as inferred from diatom, alkenone, and stable isotope records, Paleoceanography, 25, PA1206, doi:10.1029/2008PA001671, 2010.

Calvert, S. E. and Fontugne, M. R.: On the late PleistoceneHolocene sapropel record of climatic and oceanographic variability in the eastern Mediterranean. Paleoceanography, 16, 7894, 2001.

Channell, J. E. T., Xuan, C., and Hodell, D. A.: Stacking paleointensity and oxygen isotope data for the last 1.5 Myr (PISO-1500), Earth Planet. Sci. Lett., 283, 14-23, doi:10.1016/j.eps1.2009.03.012, 2009.

Chen, C.-T. A.: Shelf-vs. dissolution-generated alkalinity above the chemical lysocline, Deep-Sea Res. Pt. II, 49, 5365-5375, doi:10.1016/S0967-0645(02)00196-0, 2002.

Chikamoto, M. O., Menviel, L., Abe-Ouchi, A., Ohgaito, R., Timmermann, A., Okazaki, Y., Harada, N., Oka, A., and Mouchet, A.: Variability in North Pacific intermediate and deep water ventilation during Heinrich events in two coupled climate models, Deep-Sea Res. Pt. II, 61-64, 114-126, doi:10.1016/j.dsr2.2011.12.002, 2012. 
Cook, M. S.: The paleoceanography of the Bering Sea during the last glacial cycle, Ph.D. thesis, Massachusetts Institute of Technology, Woods Hole Oceanographic Institution, Massachusetts Institute of Technology, 126 pp., 2006.

Cook, M. S., Keigwin, L. D., and Sancetta, C. A.: The deglacial history of surface and intermediate water of the Bering Sea, DeepSea Res. Pt. II, 52, 2163-2173, doi:10.1016/j.dsr2.2005.07.004, 2005.

Crusius, J., Pedersen, T. F., Kienast, S., Keigwin, L., and Labeyrie, L.: Influence of northwest Pacific productivity on North Pacific Intermediate Water oxygen concentrations during the Bölling-Alleröd interval (14.7-12.9 ka), Geology, 32, 633-636, doi:10.1130/G20508.1, 2004.

Dansgaard, W., Johnsen, S. J., Clausen, H. B., Dahl-Jensen, D., Gundestrup, N. S., Hammer, C. U., Hvidberg, C. S., Steffensen, J. P., Svelnbjörnsdottir, A. E., Jouzel, J., and Bond, G.: Evidence for general instability of past climate from a $250-\mathrm{kyr}$ ice-core record, Nature, 364, 218-220, 1993.

Debret, M., Desmet, M., Balsam, W., Copard, Y., Francus, P., and Laj, C.: Spectrophotometer analysis of Holocene sediments from an anoxic fjord: Saanich Inlet, British Columbia, Canada, Mar. Geol., 229, 15-28, doi:10.1016/j.margeo.2006.01.005, 2006.

Dehairs, F., Stroobants, N., and Goeyens, L.: Suspended barite as a tracer of biological activity in the Southern Ocean, Mar. Chem., 35, 399-410, 1991.

De La Rocha, C. L.: The biological pump, in: Treatise on Geochemistry, vol. 6, edited by: Elderfield, H., Elsevier, Amsterdam, 83$111,2007$.

DeMaster, D.: The supply and accumulation of silica in the marine environment, Geochim. Cosmochim. Ac., 45, 1715-1732, 1981.

Duce, R. A. and Tindale, N. W.: Atmospheric transport of iron and its deposition in the ocean, Limnol. Oceanogr., 36, 1715-1726, 1991.

Dullo, W.-C., Baranov, B., and van den Bogaard, C. (Eds.): FS Sonne Fahrtbericht / Cruise Report SO201-2 KALMAR, Busan/Korea-Tomakomai/Japan, 30.08.-08.10.2009, IFMGEOMAR Report 35, Leibniz Institute of Marine Sciences, Kiel, 233 pp., 2009.

Dymond, J. and R. Collier, R.: Particulate barium fluxes and their relationships to biological productivity, Deep-Sea Res. Pt. II, 43, 1283-1308, 1996.

Dymond, J., Suess, E., and Lyle, M.: Barium in deep-sea sediment: a geochemical proxy for paleoproductivity, Paleoceanography, 7, 163-181, 1992.

Emile-Geay, J., Cane, M. A., Naik, N., Seager, R., Clement, A. C., and van Geen, A.: Warren revisited: Atmospheric freshwater fluxes and "Why is no deep water formed in the North Pacific", J. Geophys. Res., 108, 3178, doi:10.1029/2001JC001058, 2003.

Engel, A. E. J., Engel, C. G., and Havens, R. G.: Chemical characteristics of oceanic basalts and the upper Miocene, Geol. Soc. Am. Bull., 76, 719-734, 1965.

Enkin, R. J., Baker, J., Nourgaliev, D., Iassonov, P., and Hamilton, T. S.: Magnetic hysteresis parameters and Day plot analysis to characterize diagenetic alteration in gas hydrate-bearing sediments, J. Geophys. Res., 112, B06S90, doi:10.1029/2006JB004638, 2007.

Eppley, R. W. and Peterson, B. J.: Particulate organic matter flux and planktonic new production in the deep ocean, Nature, 282, 677-680, 1979.
Feely, R. A., Sabine, C. L., Lee, K., Millero, F. J., Lamb, M. F., Greeley, D., Bullister, J. L., Key, R. M., Peng, T.-H., Kozyr, A., Ono, T., and Wong, C. S.: In situ calcium carbonate dissolution in the Pacific Ocean, Global Biogeochem. Cy., 16, 1144, doi:10.1029/2002GB001866, 2002.

Francois, R., Honjo, S., Manganini, S. J., Ravizza, G. E.: Biogenic barium fluxes to the deep sea: Implications for paleoproductivity reconstruction, Global Biogeochem. Cy., 9, 289-303, 1995.

Galbraith, E. D., Jaccard, S. L., Pedersen, T. F., Sigman, D. M., Haug, G. H., Cook, M., Southon, J. R., and Francois, R.: Carbon dioxide release from the North Pacific abyss during the last deglaciation, Nature, 449, 890-893, doi:10.1038/nature06227, 2007.

Galbraith, E. D., Kienast, M., Jaccard, S. L., Pedersen, T. F., Brunelle, B. G., Sigman, D. M., and Kiefer, T.: Consistent relationship between global climate and surface nitrate utilization in the western subarctic Pacific throughout the last $500 \mathrm{ka}$, Paleoceanography, 23, PA2212, doi:10.1029/2007PA001518, 2008.

Ganeshram, R. S., Calvert, S. E., Pedersen, T. F., and Cowie, G. L.: Factors controlling the burial of organic carbon in laminated and bioturbated sediments off NW Mexico: Implications for hydrocarbon preservation, Geochim. Cosmochim. Ac., 63, 1723-1734, 1999.

Ganeshram, R. S., Francois, R., Commeau, J., and Brown-Leger, S. L.: An experimental investigation of barite formation in seawater, Geochim. Cosmochim. Ac., 67, 2599-2605, doi:10.1016/S00167037(03)00164-9, 2003.

Gardner, J. V., Dean, W. E., and Vallier, T. L.: Sedimentology and geochemistry of surface sediments, outer continental shelf, southern Bering Sea, Mar. Geol., 35, 299-329, 1980.

Gebhardt, H., Sarnthein, M., Grootes, P. M., Kiefer, T., Kühn, H., Schmieder, F., and Röhl, U.: Paleonutrient and productivity records from the subarctic North Pacific for Pleistocene glacial terminations I to V, Paleoceanography, 23, PA4212, doi:10.1029/2007PA001513, 2008.

Gingele, F., Zabel, M., Kasten, S., Bonn, W. J., and Nürnberg, C. C.: Biogenic barium as a proxy for paleoproductivity: Methods and limitations of application, in: Use of proxies in paleoceanography, Examples from the South Atlantic, edited by: Fischer, G. and Wefer, G., Springer, Berlin, 345-364, 1999.

Goñi, M. A., Ruttenberg, K. C., and Eglinton, T. I.: A reassessment of the sources and importance of land-derived organic matter in surface sediments from the Gulf of Mexico, Geochim. Cosmochim. Ac., 62, 3055-3075, 1998.

Gorbarenko, S. A.: Stable isotope and lithologic evidence of lateglacial and Holocene oceanography of the northwestern Pacific and its marginal seas, Quaternary Res., 46, 230-250, 1996.

Gorbarenko, S. A., Khusid, T. A., Basov, I. A., Oba, T., Southon, J. R., and Koizumi, I.: Glacial Holocene environment of the southeastern Okhotsk Sea: Evidence from geochemical and paleontological data, Palaeogeogr. Palaeocl., 177, 237-263, doi:10.1016/S0031-0182(01)00335-2, 2002a.

Gorbarenko, S. A., Nürnberg, D., Derkachev, A. N., Astakhov, A. S., Southon, J. R., and Kaiser, A.: Magnetostratigraphy and tephrochronology of the Upper Quaternary sediments in the Okhotsk Sea: Implication of terrigenous, volcanogenic and biogenic matter supply, Mar. Geol., 183, 107-129, doi:10.1016/S0025-3227(02)00164-0, 2002b. 
Gorbarenko, S. A., Basov, I. A., Chekhovskaya, M. P., Southon, J., Khusid, T. A., and Artemova, A. V.: Orbital and millenium scale environmental changes in the southern Bering Sea during the last glacial-Holocene: Geochemical and paleontological evidence, Deep-Sea Res. Pt. II, 52, 2174-2185, doi:10.1016/j.dsr2.2005.08.005, 2005.

Gorbarenko, S. A., Wang, P., Wang, R., and Cheng, X.: Orbital and suborbital environmental changes in the southern Bering Sea during the last $50 \mathrm{kyr}$, Palaeogeogr. Palaeocl., 286, 97-106, doi:10.1016/j.palaeo.2009.12.014, 2010.

Gromet, L. P., Dymek, R. F., Haskin, L. A., and Korotev, R. L.: The "North American shale composite": Its compilation, major and trace element characteristics, Geochim. Cosmochim. Ac., 48, 2469-2482, 1984.

Grosswald, M. G. and Hughes, T. J.: The Russian component of an Arctic Ice Sheet during the Last Glacial Maximum, Quaternary Sci. Rev., 21, 121-146, doi:10.1016/S0277-3791(01)000786, 2002.

Hartnett, H. E., Keil, R. G., Hedges, J. I., and Devol, A. H.: Influence of oxygen exposure time on organic carbon preservation in continental margin sediments, Nature, 391, 572-574, 1998.

Haug, G. H., Sigman, D. M., Tiedemann, R., Pedersen, T. F., and Sarnthein, M.: Onset of permanent stratification in the subarctic Pacific Ocean, Nature, 401, 779-782, 1999.

Haug, G. H., Ganopolski, A., Sigman, D. M., Rosell-Mele, A., Swann, G. E. A., Tiedemann, R., Jaccard, S. L., Bollmann, J., Maslin, M. A., Leng, M. J., and Eglinton, G.: North Pacific seasonality and the glaciation of North America 2.7 million years ago, Nature, 433, 821-825, doi:10.1038/nature03332, 2005.

Hedges, J. I., Clark, W. A., Quay, P. D., Richey, J. E., Devol, A. H., and de M. Santos, U.: Compositions and fluxes of particulate organic material in the Amazon River, Limnol. Oceanogr., 31, 717-738, 1986.

Hedges, J. I., Baldock, J. A., Gélinas,Y., Lee, C., Peterson, M., and Wakeham, S. G.: Evidence for non-selective preservation of organic matter in sinking marine particles, Nature, 409, 801-804, 2001.

Hendy, I. L. and Kennett, J. P.: Dansgaard-Oeschger cycles and the California Current System: Planktonic foraminiferal response to rapid climate change in Santa Barbara Basin, Ocean Drilling Program Hole 893A, Paleoceanography, 15, 30-42, 2000.

Honda, M. C., Imai, K., Nojiri, Y., Hoshi, F., Sugawara, T., and Kusakabe, M.: The biological pump in the northwestern North Pacific based on fluxes and major components of particulate matter obtained by sediment-trap experiments (19972000), Deep-Sea Res. Pt. II, 49, 5595-5625, doi:10.1016/S09670645(02)00201-1, 2002.

Honjo, S.: Particle fluxes and modern sedimentation in the polar oceans, in: Polar Oceanography, Part B. Chemistry, Biology, and Geology, edited by: Smith, W. D., Academic Press, New York, 687-739, 1990.

Hu, A., Meehl, G. A., Otto-Bliesner, B. L., Waelbroeck, C., Han, W., Loutre, M.-F., Lambeck, K., Mitrovica, J. X., and Rosenbloom, N.: Influence of Bering Strait flow and North Atlantic circulation on glacial sea-level changes, Nat. Geosci., 3, 118-121, doi:10.1038/ngeo729, 2010.

Itaki, T., Uchida, M., Kim, S., Shin, H.-S., Tada, R., and Khim, B.K.: Late Pleistocene stratigraphy and palaeoceanographic implications in northern Bering Sea slope sediments: Evidence from the radiolarian species Cycladophora davisiana, J. Quaternary Sci., 24, 856-865, doi:10.1002/jqs.1356, 2009.

Jaccard, S. L. and Galbraith, E. D.: Direct ventilation of the North Pacific did not reach the deep ocean during the last deglaciation, Geophys. Res. Lett., 40, 199-203, doi:10.1029/2012GL054118, 2013.

Jaccard, S. L., Haug, G. H., Sigman, D. M., Pedersen, T. F., Thierstein, H. R., and Röhl, U.: Glacial/interglacial changes in subarctic North Pacific stratification, Science, 308, 1003-1008, doi:10.1126/science.1108696, 2005.

Jaccard, S. L., Galbraith, E. D., Sigman, D. M., Haug, G. H., Francois, R., Pedersen, T. F., Dulski, P., and Thierstein, H. R.: Subarctic Pacific evidence for a glacial deepening of the oceanic respired carbon pool, Earth Planet. Sci. Lett., 277, 156-165, doi:10.1016/j.epsl.2008.10.017, 2009.

Jaccard, S. L., Galbraith, E. D., Sigman, D. M., and Haug, G. H.: A pervasive link between Antarctic ice core and subarctic Pacific sediment records over the past 800 kyrs, Quaternary Sci. Rev., 29, 206-212, doi:10.1016/j.quascirev.2009.10.007, 2010.

Jansen, J. H. F., van der Gaast, S. J., Koster, B., and Vaars, A. J.: CORTEX, a shipboard XRF-scanner for element analyses in split sediment cores, Mar. Geol., 151, 143-153, 1998.

Karhu, J. A., Tschudi, S., Saarnisto, M., Kubik, P., and Schlüchter, C.: Constraints for the latest glacial advance on Wrangel Island, Arctic Ocean, from rock surface exposure dating, Global Planet. Change, 31, 447-451, 2001.

Katsuki, K. and Takahashi, K.: Diatoms as paleoenvironmental proxies for seasonal productivity, sea-ice and surface circulation in the Bering Sea during the late Quaternary, Deep-Sea Res. Pt. II, 52, 2110-2130, doi:10.1016/j.dsr2.2005.07.001, 2005.

Kaufman, D. S., Forman, S. L., Lea, P. D., and Wobus, C. W.: Age of pre-late-Wisconsin glacial-eastuarine sedimentation, Bristol Bay, Alaska, Quaternary Res., 45, 59-72, 1996.

Keigwin, L. D.: Glacial-age hydrography of the far northwest Pacific Ocean, Paleoceanography, 13, 323-339, 1998.

Keigwin, L. D. and Jones, G. A.: Deglacial climatic oscillations in the Gulf of California, Paleoceanography, 5, 1009-1023, 1990.

Keigwin, L. D., Jones, G. A., and Froelich, P. N.: A 15,000 year paleoenvironmental record from Meiji Seamount, far northwestern Pacific, Earth Planet. Sci. Lett., 111, 425-440, 1992.

Keigwin, L. D., Donnelly, J. P., Cook, M. S., Driscoll, N. W., and Brigham-Grette, J.: Rapid sea-level rise and Holocene climate in the Chukchi Sea, Geology, 34, 861-864, doi:10.1130/G22712.1, 2006.

Kennett, J. P. and Ingram, B. L.: A 20,000-year record of ocean circulation and climate change from the Santa Barbara basin, Nature, 377, 510-514, 1995.

Khim, B.-K., Kim, S., Uchida, M., and Itaki, T.: High organic carbon deposition in the northern margin of the Aleutian Basin (Bering Sea) before the last deglaciation, Ocean Sci., 45, 203211, doi:10.1007/s12601-010-0019-y, 2010.

Kienast, S. S., Hendy, I. L., Crusius, J., Pedersen, T. F., and Calvert, S.: Export production in the subarctic North Pacific over the last 800 kyrs: No evidence for iron fertilization? J. Oceanogr., 60, 189-203, 2004.

Kim, S., Khim, B. K., Uchida, M., Itaki, T., and Tada, R.: Millennial-scale paleoceanographic events and implication for the intermediate-water ventilation in the northern slope area of the Bering Sea during the last 71 kyrs, Global Planet. Change, 
79, 89-98, doi:10.1016/j.gloplacha.2011.08.004, 2011.

Klump, J., Hebbeln, D., and Wefer, G.: The impact of sediment provenance on barium-based productivity estimates, Mar. Geol., 169, 259-271, 2000.

Laskar, J., Robutel, P., Joutel, F., Gastineau, M., Correia, A. C. M., and Levrard, B.: A long-term numerical solution for the insolation quantities of the Earth, Astron. Astrophys., 428, 261-285, doi:10.1051/0004-6361:20041335, 2004.

Latimer, J. C. and Filippelli, G. M.: Terrigenous input and paleoproductivity in the Southern Ocean, Paleoceanography, 16, 627643, 2001.

Lisiecki, L. and Raymo, M.: A Pliocene-Pleistocene stack of 57 globally distributed benthic $\delta^{18} \mathrm{O}$ records, Paleoceanography, 20, PA1003, doi:10.1029/2004PA001071, 2005.

Lisitzin, A. P.: Sea ice and iceberg sedimentation in the ocean: Recent and past, Springer-Verlag, Berlin, 563 pp., 2002.

Lund, D. C., Mix, A. C., and Southon, J.: Increased ventilation age of the deep northeast Pacific Ocean during the last deglaciation, Nat. Geosci., 4, 771-774, doi:10.1038/ngeo1272, 2011.

Mahowald, N. M., Baker, A. R., Bergametti, G., Brooks, N., Duce, R. A., Jickells, D., Kubilay, N., Prospero, J. M., and Tegen, I.: Atmospheric global dust cycle and iron inputs to the ocean, Global Biogeochem. Cy., 19, GB4025, doi:10.1029/2004GB002402, 2005.

Malakhov, M. I., Gorbarenko, S. A., Malakhova, G. Y., Harada, N., Vasilenko, Y. P., Bosin, A. A., Goldberg, E. L., and Derkachev, A. N.: Petromagnetic parameters of bottom sediments as indicators of the climatic and environmental changes in the central zone of the Sea of Okhotsk during the last $350 \mathrm{kyr}$, Russ. Geol. Geophys., 50, 973-982, doi:10.1016/j.rgg.2009.10.006, 2009.

Mantua, N. J., Hare, S. R., Zhang, Y., Wallace, J. M., and Francis, R. C.: A Pacific interdecadal climate oscillation with impacts on salmon production, B. Am. Meteorol. Soc., 78, 1069-1079, 1997.

Marchitto, T. M., Lynch-Stieglitz, J., and Hemming, S. R.: Deep Pacific $\mathrm{CaCO}_{3}$ compensation and glacial-interglacial atmospheric $\mathrm{CO}_{2}$, Earth Planet. Sci. Lett., 231, 317-336, doi:10.1016/j.epsl.2004.12.024, 2005.

Matsumoto, K., Oba, T., Lynch-Stieglitz, J., and Yamamoto, H.: Interior hydrography and circulation of the glacial Pacific Ocean, Quaternary Sci. Rev., 21, 1693-1704, doi:10.1016/S02773791(01)00142-1, 2002.

Max, L., Riethdorf, J.-R., Tiedemann, R., Smirnova, M., LembkeJene, L., Fahl, K., Nürnberg, D., Matul, A., and Mollenhauer, G.: Sea surface temperature variability and sea-ice extent in the subarctic northwest Pacific during the past 15,000 years, Paleoceanography, 27, PA3213, doi:10.1029/2012PA002292, 2012.

McDonald, D., Pedersen, T. F., and Crusius, J.: Multiple late Quaternary episodes of exceptional diatom production in the Gulf of Alaska, Deep-Sea Res. Pt. II, 46, 2993-3017, 1999.

McKay, J. L., Pedersen, T. F., and Kienast, S. S.: Organic carbon accumulation over the last $16 \mathrm{kyr}$ off Vancouver Island, Canada: Evidence for increased marine productivity during the deglacial, Quaternary Sci. Rev., 23, 261-281, doi:10.1016/j.quascirev.2003.07.004, 2004.

McLennan, S. M.: Sediments and soils: Chemistry and abundances, in: Rock physics and phase relations: A handbook of physical constants, edited by: Ahrens, T. J., AGU Reference Shelf 3, AGU, Washington, 8-20, 1995.
Menviel, L., Timmermann, A., Elison Timm, O., Mouchet, A., AbeOuchi, A., Chikamoto, M. O., Harada, N., Ohgaito, R., and Okazaki, Y.: Removing the North Pacific halocline: Effects on global climate, ocean circulation and the carbon cycle, DeepSea Res. Pt. II, 61-64, 106-113, doi:10.1016/j.dsr2.2011.03.005, 2012.

Middelburg, J. J., Soetaert, K., and Herman, P. M. J.: Empirical relationships for use in global diagenetic models, Deep-Sea Res. Pt. I, 44, 327-344, 1997.

Müller, P.: C/N ratios in Pacific deep-sea sediments: effect of inorganic ammonium and organic nitrogen compounds sorbed by clays, Geochim. Cosmochim. Ac., 41, 765-776, 1977.

Müller, P. and Schneider, R.: An automated leaching method for the determination of opal in sediments and particulate matter, DeepSea Res. Pt. I, 40, 425-444, 1993.

Nagashima, K., Asahara, Y., Takeuchi, F., Harada, N., Toyoda, S., and Tada, R.: Contribution of detrital materials from the Yukon River to the continental shelf sediments of the Bering Sea based on the electron spin resonance signal intensity and crystallinity of quartz, Deep-Sea Res. Pt. II, 61-64, 145-154, doi:10.1016/j.dsr2.2011.12.001, 2012.

Nakatsuka, T., Watanabe, K., Handa, N., Matsumoto, E., and Wada, E.: Glacial to interglacial surface nutrient variations of Bering deep basins recorded by $\delta^{13} \mathrm{C}$ and $\delta^{15} \mathrm{~N}$ of sedimentary organic matter, Paleoceanography, 10, 1047-1061, 1995.

Nameroff, T. J., Calvert, S. E., and Murray, J. W.: Glacialinterglacial variability in the eastern tropical North Pacific oxygen minimum zone recorded by redox-sensitive trace metals, $\mathrm{Pa}$ leocanography, 19, PA1010, doi:10.1029/2003PA000912, 2004.

Narita, H., Sato, M., Tsunogai, S., Murayama, M., Ikehara, M., Nakatsuka, T., Wakatsuchi, M., Harada, N., and Ujiié, Y.: Biogenic opal indicating less productive northwestern North $\mathrm{Pa}$ cific during the glacial ages, Geophys. Res. Lett., 29, 1732, doi:10.1029/2001GL014320, 2002.

Nelson, D. M., Tréguer, P., Brzezinski, M. A., Leynaert, A., and Quéguiner, B.: Production and dissolution of biogenic silica in the ocean: Revised global estimates, comparison with regional data and relationship to biogenic sedimentation, Global Biogeochem. Cy., 9, 359-372, 1995.

Niebauer, H. J.: Effects of El Nino-Southern Oscillation and North Pacific weather patterns on interannual variability in the subarctic Bering Sea, J. Geophys. Res., 93, 5051-5068, 1988.

Niebauer, H. J.: Variability in Bering Sea ice cover as affected by a regime shift in the North Pacific in the period 1947-1996, J. Geophys. Res., 103, 27717-27737, 1998.

Niebauer, H. J., Alexander, V., and Henrichs, S.M.: A time-series study of the spring bloom at the Bering Sea ice edge I. Physical processes, chlorophyll and nutrient chemistry. Cont. Shelf Res., 15, 1859-1877, 1995.

Niebauer, H. J., Bond, N. A., Yakunin, L. P., and Plotnikov, V. V.: An update on the climatology and sea ice of the Bering Sea, in: Dynamics of the Bering Sea, edited by: Loughlin, T. R. and Ohtani, K., University of Alaska Sea Grant, Fairbanks, Alaska, 29-59, 1999.

North Greenland Ice Core Project members: High-resolution record of northern hemisphere climate extending into the last interglacial period, Nature, 431, 147-151, doi:10.1038/nature02805, 2004. 
Nürnberg, C. C.: Bariumfluss und Sedimentation im südlichen Südatlantik-Hinweise auf Produktivitätsänderungen im Quartär, GEOMAR Reports 38, Research Center for Marine Geosciences (GEOMAR), Kiel, 105 pp., 1995.

Nürnberg, D. and Tiedemann, R.: Environmental change in the Sea of Okhotsk during the last 1.1 million years, Paleoceanography, 19, PA4011, doi:10.1029/2004PA001023, 2004.

Nürnberg, D., Wollenburg, I., Dethleff, D., Eicken, H., Kassens, H., Letzig, T., Reimnitz, E., and Thiede, J.: Sediments in Arctic sea ice: Implications for entrainment, transport and release, Mar. Geol., 119, 185-214, 1994.

Nürnberg, C. C., Bohrmann, G., Schlüter, M., and Frank, M.: Barium accumulation in the Atlantic sector of the Southern Ocean: Results from 190,000-year records, Paleoceanography, 12, 594603, 1997.

Nürnberg, D., Dethleff, D., Tiedemann, R., Kaiser, A., and Gorbarenko, S. A.: Okhotsk Sea ice coverage and Kamchatka glaciation over the last $350 \mathrm{ka}$ - Evidence from ice-rafted debris and planktonic $\delta^{18} \mathrm{O}$, Palaeogeogr. Palaeocl., 310, 191-205, doi:10.1016/j.palaeo.2011.07.011, 2011.

Ohkushi, K., Itaki, T., and Nemoto, N.: Last glacial-Holocene change in intermediate-water ventilation in the northwestern Pacific, Quaternary Sci. Rev., 22, 1477-1484, doi:10.1016/S02773791(03)00082-9, 2003.

Ohkushi, K., Uchida, M., Ahagon, N., Mishima, T., and Kanematsu, T.: Glacial intermediate water ventilation in the northwestern Pacific based on AMS radiocarbon dating, Nucl. Instrum. Meth. B, 223-224, 460-465, doi:10.1016/j.nimb.2004.04.087, 2004.

Okada, M., Takagi, M., Narita, H., and Takahashi, K.: Chronostratigraphy of sediment cores from the Bering Sea and the subarctic Pacific based on paleomagnetic and oxygen isotopic analyses, Deep-Sea Res. Pt. II, 52, 2092-2109, doi:10.1016/j.dsr2.2005.08.004, 2005.

Okazaki, Y., Takahashi, K., Asahi, H., Katsuki, K., Hori, J., Yasuda, H., Sagawa, Y., and Tokuyama, H.: Productivity changes in the Bering Sea during the late Quaternary, Deep-Sea Res. Pt. II, 52, 2150-2162, doi:10.1016/j.dsr2.2005.07.003, 2005.

Okazaki, Y., Timmermann, A., Menviel, L., Harada, N., Abe-Ouchi, A., Chikamoto, M. O., Mouchet, A., and Asahi, H.: Deepwater formation in the North Pacific during the Last Glacial Maximum, Science, 329, 200-204, doi:10.1126/science.1190612, 2010.

Orians, K. J. and Bruland, K. W.: The biogeochemistry of aluminium in the Pacific Ocean, Earth Planet. Sci. Lett., 78, 397$410,1986$.

Ortiz, J. D., O'Connell, S. B., DelViscio, J., Dean, W., Carriquiry, J. D., Marchitto, T., Zheng, Y., and van Geen, A.: Enhanced marine productivity off western North America during warm climate intervals of the past 52 k.y., Geology, 32, 521-524, doi:10.1130/G20234.1, 2004

Overland, J. E., Adams, J. M., and Bond, N. A.: Decadal variability of the Aleutian Low and its relation to high-latitude circulation, J. Climate, 12, 1542-1548, 1999.

Overland, J. E., Bond, N. A., and Adams, J. M.: The relation of surface forcing of the Bering Sea to large-scale climate patterns, Deep-Sea Res. Pt. II, 49, 5855-5868, doi:10.1016/S09670645(02)00322-3, 2002.

Paillard, D., Labeyrie, L., and Yiou, P.: Macintosh program performs time-series analysis, EOS T. Am. Geophys. Un., 77, p. 379, doi:10.1029/96EO00259, 1996.
Pondaven, P., Ragueneau, O., Tréguer, P., Hauvespre, A., Dezileau, L., and Reyss, J. L.: Resolving the 'opal paradox' in the Southern Ocean, Nature, 405, 168-172, 2000.

Pushkar, V. S., Roof, S. R., Cherepanova, M. V., Hopkins, D. M., and Brigham-Grette, J.: Paleogeographic and paleoclimatic significance of diatoms from middle Pleistocene marine and glaciomarine deposits on Baldwin Peninsula, northwestern Alaska, Palaeogeogr. Palaeocl., 152, 67-85, 1999.

Pye, K.: Aeolian dust and dust deposits, Academic Press, London, 334 pp., 1987.

Ragueneau, O., Tréguer, P., Leynaert, A., Anderson, R. F., Brzezinski, M. A., DeMaster, D. J., Dugdale, R. C., Dymond, J., Fischer, G., Francois, R., Heinze, C., Maier-Reimer, E., Martin-Jézéquel, V., Nelson, D. M., and Quéguiner, B.: A review of the Si cycle in the modern ocean: recent progress and missing gaps in the application of biogenic opal as a paleoproductivity proxy, Global Planet. Change, 26, 317-365, 2000.

Rasmussen, S. O., Andersen, K. K., Svensson, A. M., Steffensen, J. P., Vinther, B. M., Clausen, H. B., Siggaard-Andersen, M.L., Johnsen, S. J., Larsen, L. B., Dahl-Jensen, D., Bigler, M., Röthlisberger, R., Fischer, H., Goto-Azuma, K., Hansson, M. E., and Ruth, U.: A new Greenland ice core chronology for the last glacial termination, J. Geophys. Res., 111, D06102, doi:10.1029/2005JD006079, 2006.

Redfield, A. C., Ketchum, B. H., and Richards, F. A.: The influence of organisms on the composition of seawater, in: The Sea, vol. 2, edited by: Hill, M. N., Wiley-Interscience, New York, 26-77, 1963.

Reed, R. K., Khen, G. V., Stabeno, P. J., and Verkhunov, A. V.: Water properties and flow over the deep Bering Sea basin, summer 1991, Deep-Sea Res. Pt. I, 40, 2325-2334, 1993.

Rella, S. F., Tada, R., Nagashima, K., Ikehara, M., Itaki, T., Ohkushi, K., Sakamoto, T., Harada, N., and Uchida, M.: Abrupt changes of intermediate water properties on the northeastern slope of the Bering Sea during the last glacial and deglacial period, Paleoceanography, 27, PA3203, doi:10.1029/2011PA002205, 2012.

Richter, T., van der Gaast, S., Koster, B., Vaars, A., Gieles, R., de Stigter, H., De Haas, H., and van Weering, T.: The Avaatech XRF core scanner: technical description and applications to NE Atlantic sediments, in: New Techniques in Sediment Core Analyses, edited by: Rothwell, R. G., Geol. Soc. Spec. Publ., 267, 39-50, doi:10.1144/GSL.SP.2006.267.01.03, 2006.

Riethdorf, J.-R., Max, L., Nürnberg, D., Lembke-Jene, L., and Tiedemann, R.: Deglacial development of (sub) sea surface temperature and salinity in the subarctic northwest Pacific: Implications for upper-ocean stratification, Paleoceanography, 28, 91104, doi:10.1002/palo.20014, 2013.

Ronov, A. B. and Migdisov, A. A.: Geochemical history of the crystalline basement and the sedimentary cover of the Russian and North American platforms, Sedimentology, 16, 137-185, 1971.

Rösler, H. J. and Lange, H.: Geochemical tables, Elsevier, New York, 468 pp., 1972.

Ruth, U., Wagenbach, D., Steffensen, J. P., and Bigler, M.: Continuous record of microparticle concentration and size distribution in the central Greenland NGRIP ice core during the last glacial period, J. Geophys. Res., 108, 4098, doi:10.1029/2002JD002376, 2003. 
Sagawa, T. and Ikehara, K.: Intermediate water ventilation change in the subarctic northwest Pacific during the last deglaciation, Geophys. Res. Lett., 35, L24702, doi:10.1029/2008GL035133, 2008.

Sancetta, C.: Effect of Pleistocene glaciation upon oceanographic characteristics of the North Pacific Ocean and Bering Sea, DeepSea Res., 30, 851-869, 1983.

Sarnthein, M., Stattegger, K., Dreger, D., Erlenkeuser, H., Grootes, P., Haupt, B. J., Jung, S., Kiefer, T., Kuhnt, W., Pflaumann, U., Schäfer-Neth, C., Schulz, H., Schulz, M., Seidov, D., Simstich, J., van Kreveld, S., Vogelsang, E., Völker, A., and Weinelt, M.: Fundamental modes and abrupt changes in North Atlantic circulation and climate over the last $60 \mathrm{ky}$ - Concepts, reconstruction and numerical modeling, in: The northern North Atlantic: A changing environment, edited by: Schäfer, P., Ritzrau, W., Schlüter, M., and Thiede, J., Springer, Berlin, 365-410, 2001.

Sarnthein, M., Grootes, P. M., Kennett, J. P., and Nadeau, M.-J.: ${ }^{14} \mathrm{C}$ reservoir ages show deglacial changes in ocean currents and carbon cycle, in: Past and Future Changes of the Oceanic Meridional Overturning Circulation: Mechanisms and Impacts, edited by: Schmittner, A., Chiang, J. C. H., and Hemming, S. R., AGU Monograph Series 173, AGU, Washington, D.C., 175-196, 2007.

Sato, M. M., Narita, H., and Tsunogai, S.: Barium increasing prior to opal during the last termination of glacial ages in the Okhotsk Sea sediments, J. Oceanogr., 58, 461-467, 2002.

Schlitzer, R.: Ocean Data View, available at: http://odv.awi.de (last access: 6 August 2012), 2011.

Schmitz, B.: The $\mathrm{TiO}_{2} / \mathrm{Al}_{2} \mathrm{O}_{3}$ ratio in the Cenozoic Bengal abyssal fan sediments and its use as a paleostream energy indicator, Mar. Geol., 76, 195-206, 1987.

Schneider, R. R., Price, B., Müller, P. J., Kroon, D., and Alexander, I.: Monsoon related variations in Zaire (Congo) sediment load and influence of fluvial silicate supply on marine productivity in the east equatorial Atlantic during the last 200,000 years, Paleoceanography, 12, 463-481, 1997.

Seki, O., Kawamura, K., Nakatsuka, T., Ohnishi, K., Ikehara, M., and Wakatsuchi, M.: Sediment core profiles of long-chain nalkanes in the Sea of Okhotsk: Enhanced transport of terrestrial organic matter from the last deglaciation to the early Holocene, Geophys. Res. Lett., 30, 1001, doi:10.1029/2001GL014464, 2003.

Shackleton, N. J. and Hall, M. A.: Oxygen and carbon isotope stratigraphy of Deep Sea Drilling Project Hole 552A: Plio-Pleistocene glacial history, in: Initial Reports DSDP, 81, edited by: Roberts, D. G., Schnitker, D., Backman, J., Baldauf, J. G., Desprairies, A., Homrighausen, R., Huddlestun, P., Kaltenback, A. J., Krumsiek, K. A. O., Morton, A. C., Murray, J. W., Westberg-Smith, J., and Zimmermann, H. B., US Govt. Printing Office, Washington, 599-609, doi:10.2973/dsdp.proc.81.116.1984, 1984.

Shigemitsu, M., Narita, H., Watanabe, Y. W., Harada, N., and Tsunogai, S.: Ba, Si, U, Al, Sc, La, Th, $\mathrm{C}$ and ${ }^{13} \mathrm{C} /{ }^{12} \mathrm{C}$ in a sediment core in the western subarctic Pacific as proxies of past biological production, Mar. Chem., 106, 442-455, doi:10.1016/j.marchem.2007.04.004, 2007.

Sigman, D. M. and Boyle, E. A.: Glacial/interglacial variations in atmospheric carbon dioxide, Nature, 407, 859-869, 2000.

Sigman, D. M., Jaccard, S. L., and Haug, G. H.: Polar ocean stratification in a cold climate, Nature, 428, 59-63, doi:10.1038/nature02357, 2004.

Sigman, D. M., Hain, M. P., and Haug, G. H.: The polar ocean and glacial cycles in atmospheric $\mathrm{CO}_{2}$ concentration, Nature, 466, 47-55, doi:10.1038/nature09149, 2010.

Springer, A. M., McRoy, C. P., and Flint, M. V.: The Bering Sea green belt: shelf-edge processes and ecosystem production, Fish. Oceanogr., 5, 205-223, 1996.

Stabeno, P. J., Schumacher, J. D., and Ohtani, K.: The physical oceanography of the Bering Sea, in: Dynamics of the Bering Sea, edited by: Loughlin, T. R. and Ohtani, K., University of Alaska Sea Grant, Fairbanks, Alaska, 1-28, 1999.

Stein, R.: Arctic Ocean sediments: Processes, proxies, and paleoenvironment, in: Developments in Marine Geology, vol. 2, edited by: Chamley, H., Elsevier, Amsterdam, 592 pp., 2008.

Széréméta, N., Bassinot, F., Balut, Y., Labeyrie, L., and Pagel, M.: Oversampling of sedimentary series collected by giant piston corer: Evidence and corrections based on 3.5-kHz chirp profiles, Paleoceanography, 19, PA1005, doi:10.1029/2002PA000795, 2004.

Takahashi, K.: The Bering and Okhotsk Sea: Modern and past paleoceanographic changes and gateway impact, J. Asian Earth Sci., 16, 49-58, 1998.

Takahashi, K.: Paleoceanographic changes and present environment of the Bering Sea, in: Dynamics of the Bering Sea, edited by: Loughlin, T. R. and Ohtani, K., University of Alaska Sea Grant, Fairbanks, Alaska, 365-385, 1999.

Takahashi, K.: The Bering Sea and paleoceanography, DeepSea Res. Pt. II, 52, 2080-2091, doi:10.1016/j.dsr2.2005.08.003, 2005.

Takahashi, T., Sutherland, S. C., Sweeney, C., Poisson, A., Metzl, N., Tilbrook, B., Bates, N., Wanninkhof, R., Feely, R. A., Sabine, C., Olafsson, J., and Nojiri, Y.: Global sea-air $\mathrm{CO}_{2}$ flux based on climatological surface ocean $\mathrm{pCO}_{2}$ and seasonal biological and temperature effects, Deep-Sea Res. Pt. II, 49, 1601-1622, doi:10.1016/S0967-0645(02)00003-6, 2002a.

Takahashi, K., Fujitani, N., and Yanada, M.: Long term monitoring of particle fluxes in the Bering Sea and the central subarctic Pacific Ocean, 1990-2000, Progr. Oceanogr., 55, 95-112, doi:10.1016/S0079-6611(02)00072-1, 2002b.

Takahashi, K., Ravelo, A. C., Alvarez Zarikian, C. A., and the Expedition 323 Scientists: Bering Sea Paleoceanography, Proceedings of the Integrated Ocean Drilling Program, 323, Tokyo (Integrated Ocean Drilling Program Management International, Inc.), doi:10.2204/iodp.proc.323.2011, 2011.

Tanaka, S. and Takahashi, K.: Late Quaternary paleoceanographic changes in the Bering Sea and the western subarctic Pacific based on radiolarian assemblages, Deep-Sea Res. Pt. II, 52, 2131-2149, doi:10.1016/j.dsr2.2005.07.002, 2005.

Taylor, S. R.: Abundance of chemical elements in the continental crust: a new table, Geochim. Cosmochim. Ac., 28, 1273-1285, 1964.

Taylor, S. R. and McLennan, S. M.: The geochemical evolution of the continental crust, Rev. Geophys., 33, 241-265, 1995.

Taylor, S. R., McLennan, S. M., and McCulloch, M. T.: Geochemistry of loess, continental crust composition and crustal model ages, Geochim. Cosmochim. Ac., 47, 1897-1905, 1983.

Ternois, Y., Kawamura, L., Keigwin, L., Ohkouchi, N., and Nakatsuka, T.: A biomarker approach for assessing marine and terrigenous inputs to the sediments of Sea of Okhotsk for the last 27,000 
years, Geochim. Cosmochim. Ac., 65, 791-802, 2001.

Thunell, R. C., Varela, R., Llano, M., Collister, J., Muller-Karger, F., and Bohrer, R.: Organic carbon fluxes, degradation, and accumulation in an anoxic basin: Sediment trap results from the Cariaco Basin, Limnol. Oceanogr., 45, 300-308, 2000.

Tjallingii, R., Röhl, U., Kölling, M., and Bickert, T.: Influence of the water content on X-ray fluorescence core-scanning measurements in soft marine sediments, Geochem. Geophy. Geosy., 8, Q02004, doi:10.1029/2006GC001393, 2007.

Tomczak, M. and Godfrey, J. S.: Regional oceanography: An introduction, Elsevier Science Ltd., Oxford, 391 pp., 1994.

Tyrrell, T., Merico, A., Waniek, J. J., Wong, C. S., Metzl, N., and Whitney, F.: Effect of seafloor depth on phytoplankton blooms in high-nitrate, low-chlorophyll (HNLC) regions, J. Geophys. Res., 110, G02007, doi:10.1029/2005JG000041, 2005.

van Geen, A., Zheng, Y., Bernhard, J. M., Cannariato, K. G., Carriquiry, J., Dean, W. E., Eakins, B. W., Ortiz, J. D., and Pike, J.: On the preservation of laminated sediments along the western margin of North America, Paleoceanography, 18, 1098, doi:10.1029/2003PA000911, 2003.

VanLaningham, S., Pisias, N. G., Duncan, R. A., and Clift, P. D.: Glacial-interglacial sediment transport to the Meiji Drift, northwest Pacific Ocean: Evidence for timing of Beringian outwashing, Earth Planet. Sci. Lett., 277, 64-72, doi:10.1016/j.eps1.2008.09.033, 2009.

Waelbroeck, C., Labeyrie, L., Michel, E., Duplessy, J. C., McMannus, J. F., Lambeck, K., Balbon, E., and Labracherie, M.: Sealevel and deep water temperature changes derived from benthic foraminifera isotopic records, Quaternary Sci. Rev., 21, 295-305, doi:10.1016/S0277-3791(01)00101-9, 2002.

Wang, Y. J., Cheng, H., Edwards, R. L., An, Z. S., Wu, J. Y., Shen, C.-C., and Dorale, J. A.: A high-resolution absolute-dated Late Pleistocene monsoon record from Hulu cave, China, Science, 294, 2345-2348, 2001.
Wang, Y., Cheng, H., Edwards, R. L., Kong, X., Shao, X., Chen, S., Wu, J., Jiang, X., Wang, X., and An, Z.: Millennial- and orbitalscale changes in the East Asian monsoon over the past 224,000 years, Nature, 451, 1090-1093, doi:10.1038/nature06692, 2008.

Warren, B.: Why is no deepwater formed in the North Pacific? J. Mar. Res., 41, 327-347, 1983.

Wedepohl, K. H.: Environmental influences on the chemical composition of shales and clays, in: Physics and chemistry of the Earth, edited by: Ahrens, L., Press, K., Runcorn, S., and Urey, H., Pergamon Press, Oxford, 307-333, 1971.

Yarincik, K. M., Murray, R. W., and Peterson, L. C.: Climatically sensitive eolian and hemipelagic deposition in the Cariaco Basin, Venezuela, over the past 578,000 years: Results from A1/Ti and K/Al, Paleoceanography, 15, 210-228, 2000.

Yasonov, P. G., Nourgaliev, D. C., Bourov, B. V., and Heller, F.: A modernized coercivity spectrometer, Geol. Carpath., 49, 224 226, 1998.

Yasuda, I.: The origin of the North Pacific Intermediate Water, J. Geophys. Res., 102, 893-909, 1997.

Zhang, J., Woodgate, R., and Moritz, R.: Sea ice response to atmospheric and oceanic forcing in the Bering Sea, J. Phys. Oceanogr., 40, 1729-1747, doi:10.1175/2010JPO4323.1, 2010.

Zheng, Y., van Geen, A., Anderson, R. F., Gardner, J. V., and Dean, W. E.: Intensification of the northeast Pacific oxygen minimum zone during the Bölling-Alleröd warm period, Paleoceanography, 15, 528-536, 2000.

Ziegler, M., Jilbert, T., de Lange, G. J., Lourens, L. J., and Reichart, G.-J.: Bromine counts from XRF scanning as an estimate of the marine organic carbon content of sediment cores, Geochem. Geophy. Geosy., 9, Q05009, doi:10.1029/2007GC001932, 2008. 